\title{
Flow and geochemistry of groundwater beneath a back-barrier lagoon: The subterranean estuary at Chincoteague Bay, Maryland, USA
}

\author{
John F. Bratton ${ }^{\mathrm{a}, *}$, John Karl Böhlke ${ }^{\mathrm{b}}$, David E. Krantz ${ }^{\mathrm{c}}$, Craig R. Tobias ${ }^{\mathrm{d}}$ \\ a USGS, 384 Woods Hole Rd., Woods Hole, MA, 02543, USA \\ b USGS, 431 National Center, 12201 Sunrise Valley Drive, Reston, VA 20192, USA \\ c Dept. of Environmental Sciences, The University of Toledo, 2801 West Bancroft Street, MS \#604, Toledo, OH 43606, USA \\ d Dept. of Earth Sciences, University of North Carolina at Wilmington, 601 South College Road, Wilmington, NC 28403, USA
}

\section{A R T I C L E I N F O}

\section{Article history:}

Received 7 February 2008

Received in revised form 16 December 2008

Accepted 5 January 2009

Available online 21 January 2009

\section{Keywords:}

Submarine groundwater

Nutrients

Isotopes

Drilling

Estuary

Chincoteague Bay

\begin{abstract}
A B S T R A C T
To better understand large-scale interactions between fresh and saline groundwater beneath an Atlantic coastal estuary, an offshore drilling and sampling study was performed in a large barrier-bounded lagoon, Chincoteague Bay, Maryland, USA. Groundwater that was significantly fresher than overlying bay water was found in shallow plumes up to $8 \mathrm{~m}$ thick extending more than $1700 \mathrm{~m}$ offshore. Groundwater saltier than bay surface water was found locally beneath the lagoon and the barrier island, indicating recharge by saline water concentrated by evaporation prior to infiltration. Steep salinity and nutrient gradients occur within a few meters of the sediment surface in most locations studied, with buried peats and estuarine muds acting as confining units. Groundwater ages were generally more than 50 years in both fresh and brackish waters as deep as $23 \mathrm{~m}$ below the bay bottom. Water chemistry and isotopic data indicate that freshened plumes beneath the estuary are mixtures of water originally recharged on land and varying amounts of estuarine surface water that circulated through the bay floor, possibly at some distance from the sampling location. Ammonium is the dominant fixed nitrogen species in saline groundwater beneath the estuary at the locations sampled. Isotopic and dissolved-gas data from one location indicate that denitrification within the subsurface flow system removed terrestrial nitrate from fresh groundwater prior to discharge along the western side of the estuary. Similar situations, with one or more shallow semi-confined flow systems where groundwater geochemistry is strongly influenced by circulation of surface estuary water through organicrich sediments, may be common on the Atlantic margin and elsewhere.
\end{abstract}

Published by Elsevier B.V.

\section{Introduction}

Like many coastal embayments in agriculturally and residentially developed areas, Chincoteague Bay, a barrier-bounded estuary in Maryland and Virginia (Fig. 1), is experiencing nutrient overenrichment. In this location the problem is of particular concern to its primary managers, the National Park Service and the Maryland Department of Natural Resources. Excess nutrients are reported to have contributed to problematic macroalgal blooms and brown tides (Wazniak and Hall, 2005). A recent assessment of the health of the ecosystems in Maryland's coastal bays indicated the presence of 13 algal species that are potentially harmful based on toxicity or overabundance (Wazniak and Hall, 2005). Several studies have documented elevated nutrient concentrations in groundwater throughout the Delmarva Peninsula between Chesapeake Bay and Delaware Bay (Denver, 1986, 1989; Shedlock et al., 1999). Results indicate that subestuarine discharge of groundwater recharged in

\footnotetext{
* Corresponding author. Tel.: +1 508457 2254; fax: +1 5084572310 E-mail address: jbratton@usgs.gov (J.F. Bratton).
}

agricultural areas on land might be a contributor of nitrogen to Chincoteague Bay, and to harmful algal blooms (by association). Septic systems also contribute nutrients to the bay. Site-specific studies, such as the one described here, are necessary to make possible broader characterization of the distribution of, and controls on, submarine groundwater discharge (Taniguchi et al., 2002), and to determine the relative significance of this part of the regional and global nitrogen cycles (Slomp and Van Cappellen, 2004; Hulth et al., 2005). Previous studies by other investigators have primarily focused on the impact of submarine groundwater discharge on surface water chemistry of estuaries and the coastal ocean (Moore, 1996; Swarzenski et al., 2006a), or the relatively shallow or nearshore portions of subterranean estuaries (e.g., the low-salinity discharge face closest to shore) (Taniguchi et al., 2002; Burnett et al., 2003, 2006; Gallardo and Marui, 2006; Swarzenski et al., 2006b), but a larger scale picture of the deeper parts of these groundwater systems and areas of discharge or saline recharge farther offshore has generally been lacking.

Previous efforts to delineate the groundwater component of Chincoteague Bay's water and nutrient budgets have concentrated on groundwater discharge to 17 non-tidal streams, and have included 


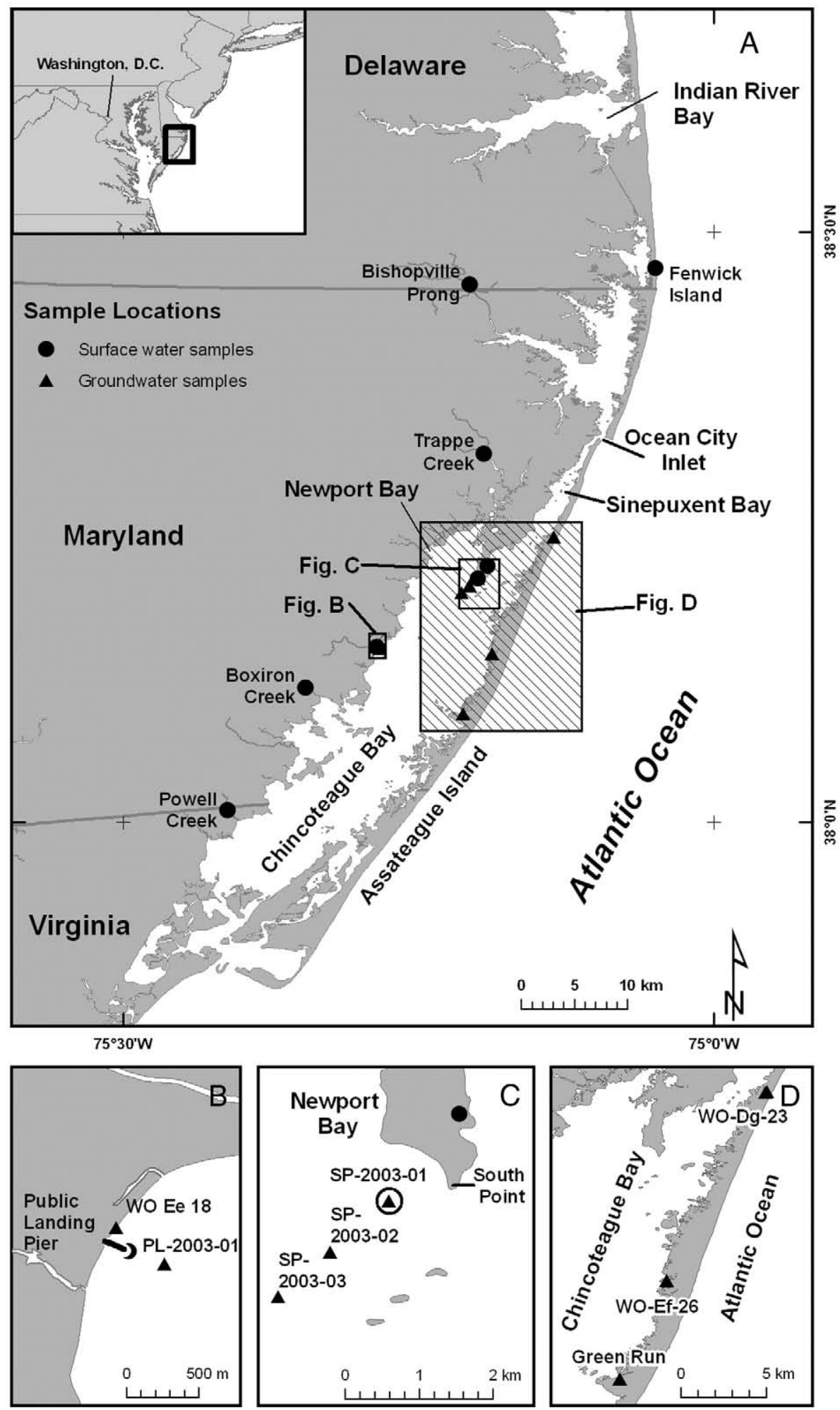

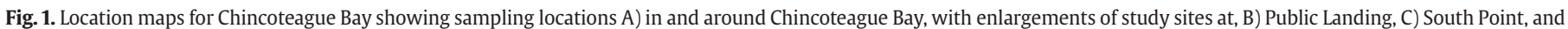

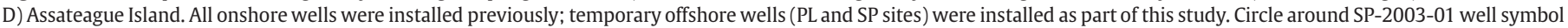
in $\mathrm{C}$ ) indicates that a surface water sample was also taken at this location.

measurements of hydraulic head and water age and quality in 28 monitoring wells on the mainland and the barrier island (Dillow and Greene, 1999; Dillow et al., 2002). These studies were inconclusive about the role and mode of direct groundwater discharge to the bay because of a lack of offshore data. The total load of new, mostly anthropogenic N to Chincoteague Bay, Newport Bay, and Sinepuxent Bay has been estimated at about 200,000 kg N/yr (Jordan, 2004), using a model incorporating data from agriculture (fertilizer application, crop fixation of $\mathrm{N}$ ), atmospheric deposition and volatilization, and trade in food and feed. As much as $55 \%$ of the load of $\mathrm{N}$ 
to Maryland's coastal bays (including Chincoteague Bay) is from atmospheric deposition, either directly deposited on the water surface or delivered to the bays in runoff (Boynton et al., 1993). A complete understanding of the role of groundwater nitrogen in this and similar estuary systems requires further examination of subsurface delivery of nitrogen, and the ability to distinguish new terrestrial nitrogen inputs from regenerated nitrogen inputs (e.g., from mineralization of organic matter) in the groundwater.

Chincoteague Bay is a shallow lagoon approximately $50 \mathrm{~km}$ long and 7 to $9 \mathrm{~km}$ wide with a tidal range generally less than $0.5 \mathrm{~m}$. It is oriented northeast-southwest and is separated from the Atlantic Ocean to the east by a long barrier island, Assateague Island. The bay is flushed by inlets on the northeast end (Ocean City Inlet, opened in 1933) and the southwest end (Chincoteague Inlet), with a flushing time of up to 63 days (Pritchard,1960). The average depth of the bay is $1.2 \mathrm{~m}$, and the surface area is $377 \mathrm{~km}^{2}$. The surface area of the bay's topographic watershed is $316 \mathrm{~km}^{2}$, which is only $84 \%$ of the surface area of the bay itself. The maximum land surface elevation in the watershed is approximately $13 \mathrm{~m}$ above sea level. Approximately one third of the watershed is agricultural land, primarily planted with corn and soybeans; about half of the land in the watershed is forested, and one fifth consists of inland and tidal wetlands (Accomack County Planning Commission, 1997; Worcester County Planning Commission, 2006). Residential development in the watershed is mostly limited to small towns and rural dwellings; the yearround population of about 50,000 swells to a peak of over 100,000 in the summer.

A detailed description of the stratigraphic units and associated surficial and shallow confined aquifers in the basin is provided by Dillow et al. (2002). The region is underlain by relatively finegrained deposits with a total thickness of about $15 \mathrm{~m}$ (Sinepuxent and/or Omar Formations, of late and middle Pleistocene age, respectively), overlying $20 \mathrm{~m}$ of coarser deposits (Beaverdam Formation, of Pliocene age) based on results of Ocean Drilling Program Leg 174AX drilling at Bethany Beach, Delaware (Miller et al., 2003) and other studies (Owens and Denny, 1978; Dillow et al., 2002). Shallow sediments in the bay consist of silt and clay in the middle and western part, with overwash sand common along the west side of Assateague Island and extending more than halfway across the bay in some areas (Wells and Conkwright, 1999). Drilling locations for the study described here were selected, in part, to investigate the nature of high electrical resistivity anomalies identified in previous surveys near South Point and Public Landing in Chincoteague Bay (Manheim et al., 2004), and to extend results from shoreline well installations at Public Landing and on Assateague Island (Dillow et al., 2002) into the offshore.

\section{Methods}

In August 2003 a complex subsurface field investigation was carried out to examine the occurrence and chemistry of subestuarine groundwater beneath Chincoteague Bay. Offshore work at four sites (Fig. 1; Supplemental Material, Table C.1), consisting of rotary drilling, downhole geophysical logging, and sampling of groundwater, sediments, and surface water, was performed from a spud barge platform. This was augmented with onshore logging of four existing wells (one on the mainland at Public Landing, and three on Assateague Island; Fig. 1; Supplemental Material, Table C.1), and collection of surface water samples from shore at bay and ocean sites, and from four creeks that flow into Chincoteague Bay or adjacent bays (Fig. 1, Supplemental Material, Table C.1). The maximum drilling depth reached offshore was $23 \mathrm{~m}$ beneath the sediment surface. The approach to logging, sampling, and analysis used in this investigation was similar to that employed in a previous investigation in Delaware (Böhlke and Krantz, 2003; Bratton et al., 2004; Krantz et al., 2004). A brief description of field and laboratory methods is included here; more details are provided in Section A of the Supplemental Material (sections A.1 through A.4).

\subsection{Drilling, logging, and sampling}

Downhole geophysical logs and samples of groundwater (pumped from temporary wells) or porewater (squeezed from sediments) were collected in two areas of Chincoteague Bay during this investigation: adjacent to Public Landing on the central western shore, and in a north-south transect extending offshore from South Point in the northern end of the bay, between Newport Bay and Sinepuxent Bay (Fig. 1). Surface-water samples also were collected at South Point and Public Landing to constrain the chemistry of the estuarine endmember.

Barge-based drilling was performed using steel casing, advanced by spinning and washing with pumped bay water, and included sampling of the upper $6 \mathrm{~m}$ of sediment at each site (Supplemental Material, Table C.2). Downhole geophysical logging was performed at drilling sites to provide continuous profiles of subsurface data from which subsurface lithology and subestuarine groundwater salinity could be interpreted between actual sampling depths. Logs were obtained prior to installation of temporary monitoring wells, by drilling to the maximum depth, and then inserting a blank PVC riser pipe filled with fresh water and withdrawing the steel casing. Geophysical logs of the boreholes were collected using a PGA-1000 gamma-logging tool (primarily sensitive to lithologic variations) and a PIA-1000 electromagnetic-induction (EM) probe (primarily sensitive to variations in groundwater salinity). Logs also were obtained from four previously installed wells (Dillow and Greene, 1999; Dillow et al., 2002) at Public Landing and on Assateague Island (Fig. 1A, B, and D).

Small volumes of pore fluid were extracted from sediments using a Manheim-type hydraulic sediment squeezer (Manheim and Gieskes, 1984; Manheim et al., 1994) and filtered. Because of the small sample volumes, salinity of filtered samples was determined in the field using an optical refractometer, which yielded values within 1.6 units or less of those measured by the Hydrolab ${ }^{\circledR}$ instrument described below on larger volume samples measured for comparison $(n=4)$.

Subestuarine groundwater samples were collected at all drilling locations by pumping from temporary wells screened at depth intervals that were identified by logging as possible groundwater conduits (zones of coarser sediments with low gamma activity and low EM conductivity). Temporary wells were installed with $5.1-\mathrm{cm}$ PVC riser through steel casing in new drill holes adjacent to geophysical logging holes. Well screens were generally $71 \mathrm{~cm}$ long, except for the first well at SP-2003-03 where a 120-cm screen was used. In the data table and text that follow, the nominal depth for well samples used is the midpoint of the well screen in meters below the sediment surface (Supplemental Material, Table C.3). Specific conductance, $\mathrm{pH}$, temperature, dissolved oxygen $\left(\mathrm{O}_{2}\right)$, and oxidationreduction potential were determined in the field during development and sampling using a calibrated Hydrolab® monitoring instrument. Immediately after development was completed and field parameters stabilized, samples were pumped through nylon tubing from just above the level of the well screen using a submersible, pneumatically-driven, Bennett piston pump. At three of four sites, wells were installed sequentially at three discrete depths working from shallow to deep in the same borehole, with all wells at each site being installed, developed, and sampled on the same day. In some cases, water levels were allowed to equilibrate in wells after sampling and relative head differences were measured between water levels in the wells and surface water levels. Surface water samples were collected from three Chincoteague Bay locations, four streams, and one Atlantic Ocean location (Fenwick Island) (Fig. 1; Supplemental Material, Table C.1). Samples of surface water were analyzed for a subset of the groundwater parameters listed below, using the same methods. 


\subsection{Laboratory analyses}

Samples for nutrient analyses were filtered ( $0.2 \mu \mathrm{m}$ pore size $)$ in the field, placed on ice, and stored frozen prior to analysis. Dissolved ammonium $\left(\mathrm{NH}_{4}^{+}\right)$, nitrate + nitrite $\left(\mathrm{NO}_{3}^{-}+\mathrm{NO}_{2}^{-}\right.$, abbreviated $\mathrm{NO}_{2+3}$ or simply referred to as "nitrate" subsequently), phosphate $\left(\mathrm{PO}_{4}^{3-}\right)$, and reactive silicate $\left(\mathrm{Si}(\mathrm{OH})_{4}\right.$, abbreviated $\mathrm{Si}$ ) were determined by automated colorimetry using an autoanalyzer (see also Supplemental Material, Section A). Typical precisions for analyses of low original or diluted concentrations of $\mathrm{NH}_{4}^{+}, \mathrm{NO}_{2+3}$, and $\mathrm{PO}_{4}^{3-}$ were approximately $\pm 0.2-1, \pm 1-5$, and $\pm 0.02-0.05 \mu \mathrm{mol} \mathrm{L}-1$, respectively.

Pumped samples collected from the temporary wells also were analyzed for major dissolved gases $\left(\mathrm{Ar}, \mathrm{N}_{2}, \mathrm{O}_{2}, \mathrm{CH}_{4}\right), \mathrm{Ne}, \mathrm{He}, \mathrm{He}$ isotopes, ${ }^{3} \mathrm{H}$, chlorofluorocarbons (CFC11, CFC12, CFC113), $\mathrm{SF}_{6}, \delta^{2} \mathrm{H}$, $\delta^{18} \mathrm{O}$ of water, and $\delta^{15} \mathrm{~N}$ of $\mathrm{NH}_{4}^{+}$and $\mathrm{N}_{2}$, generally following methods described by Böhlke and Krantz (2003). Sediment core samples were analyzed for total $\mathrm{C}$ and $\mathrm{N}$ concentrations, and $\mathrm{N}$ isotopes. Major gas analyses were done by gas chromatography on low-pressure headspace (http://water.usgs.gov/lab/dissolved-gas). Samples for $\mathrm{He}, \mathrm{Ne}$, and ${ }^{3} \mathrm{H}-{ }^{3} \mathrm{He}$ age determination were collected in flow-through copper tubes that were crimp-sealed in the field. He and Ne were extracted for mass-spectrometric (MS) analysis, then degassed aliquots of the water were re-analyzed after several months to determine ${ }^{3} \mathrm{H}$ concentrations from ${ }^{3} \mathrm{He}$ in-growth (Ludin et al., 1998). Tritium also was analyzed by electrolytic enrichment and liquid scintillation counting at USGS, Menlo Park (R.L. Michel, written comm.) with similar results. Samples to be analyzed for chlorofluorocarbons (CFCs) and $\mathrm{SF}_{6}$ were collected unfiltered with no headspace, extracted by a purge-and-trap procedure, and analyzed by gas chromatography with an electron-capture detector (Busenberg and Plummer, 1992, 2000; http://water.usgs.gov/lab/).

Concentrations of $\mathrm{Ne}, \mathrm{Ar}$, and $\mathrm{N}_{2}$ were used to calculate recharge temperatures, excess air (assumed to be unfractionated), and excess $\mathrm{N}_{2}$ in each sample (e.g., Aeschbach-Hertig et al., 1999; Stute and Schlosser; 2000), as described by Böhlke and Krantz (2003). For each sample, the measured concentrations of CFC11, CFC12, CFC113, and $\mathrm{SF}_{6}$ were converted to equilibrium partial pressures at sea level, adjusted for the measured salinities at the equilibration temperatures and excess air concentrations indicated by the dissolved-gas data (Bullister et al., 2002; E. Busenberg, written communication, 2005). Concentrations of tritiogenic ${ }^{3} \mathrm{He}$ were estimated from total He concentrations and ${ }^{3} \mathrm{He} /{ }^{4} \mathrm{He}$ ratios after adjustments for atmospheric and terrigenic He contributions (Schlosser et al., 1988). Terrigenic He contributions were relatively low at the Public Landing sites (5-8\% of total $\mathrm{He}$ ) and relatively high at the South Point sites (18-72\% of total He). Concentrations of ${ }^{3} \mathrm{H},{ }^{3} \mathrm{H} /{ }^{3} \mathrm{H}^{\circ}$ ratios $\left({ }^{3} \mathrm{H}^{\circ}={ }^{3} \mathrm{H}+{ }^{3} \mathrm{He}\right.$ [tritiogenic], the reconstructed initial ${ }^{3} \mathrm{H}$ concentration at the time of recharge, corrected for decay), and the partial pressures of $\mathrm{CFCs}$ and $\mathrm{SF}_{6}$ were compared with atmospheric records to determine apparent ages of groundwater samples, and to evaluate simple age mixtures (Cook and Herczeg, 2000).

The $\mathrm{N}$ isotopes in $\mathrm{NH}_{4}^{+}$were analyzed by a $\mathrm{NH}_{3}$ diffusion method (Holmes et al., 1998; Hannon and Böhlke, 2008). The $\delta^{15} \mathrm{~N}$ values were calibrated by analyzing ammonium isotopic reference materials as samples and are reported with respect to atmospheric $\mathrm{N}_{2}$ and normalized to values of the reference materials IAEA-N1 (+0.4\%) and USGS26 (+53.7\%) (Böhlke and Coplen, 1995), with average reproducibility of approximately $\pm 0.2 \%$. Sediment samples for isotopic analysis were flash-combusted in an elemental analyzer (EA), from which the gases were flushed with He through a Porapak ${ }^{\circledR}$ PQS chromatographic column, and into an isotope ratio mass spectrometer. Sediment $\mathrm{C}$ and $\mathrm{N}$ concentrations and $\delta^{15} \mathrm{~N}$ values were calibrated by analyses of reference materials USGS40 and USGS41 (Qi et al., 2003), with reproducibility of approximately $\pm 0.2 \%$ 。 for $\delta^{15} \mathrm{~N}$. For $\mathrm{N}$ isotope analyses of dissolved $\mathrm{N}_{2}$, the headspace gas remaining in bottles after gas chromatography was pressurized with He, then released to a closed loop and flushed through a gas chromatograph and into an isotope-ratio mass spectrometer. Results were calibrated against samples of $\mathrm{N}_{2}$ in air $\left(\delta^{15} \mathrm{~N}=0.0 \%\right.$ o $)$ and laboratory-equilibrated water $\left(\delta^{15} \mathrm{~N}=+0.65 \%\right.$ o $\pm 0.10 \%$ 。 $)$ that were collected and analyzed the same way as the samples.

Water samples to be analyzed for $\mathrm{H}$ and $\mathrm{O}$ isotopes $\left(\delta^{2} \mathrm{H}\right.$ and $\left.\delta^{18} \mathrm{O}\right)$ were collected in glass bottles and analyzed at the USGS Reston Stable Isotope Laboratory (http://isotopes.usgs.gov/) by $\mathrm{H}_{2}$ and $\mathrm{CO}_{2}$ equilibration and mass spectrometry. Values of $\delta^{2} \mathrm{H}$ and $\delta^{18} \mathrm{O}$ were normalized to the VSMOW-SLAP scale (Coplen, 1988) with uncertainties of approximately $\pm 1 \%$ o and $\pm 0.1 \%$ 。 $(1 \sigma)$, respectively.

\section{Results}

Consistent with previous onshore drilling and offshore geophysical surveys using continuous resistivity profiling methods (Manheim et al., 2004), the new offshore drilling and logging results show that: 1) a zone of relatively old, low-nutrient, low-salinity groundwater greater than $7.5 \mathrm{~m}$ thick extends more than $500 \mathrm{~m}$ offshore along the western side of Chincoteague Bay (Public Landing site); 2) a similar plume is present at the northern end of the bay (South Point sites); and 3) hypersaline brines and deep fresh groundwater underlie parts of Assateague Island. Pumped well samples yielded tritium concentrations less than 2 tritium units (TU) in almost all of the groundwaters, compared to 4-5 TU in local modern precipitation and surface water (see discussion below), so the groundwaters are mostly older than 50 years (or mixtures of water older and younger than 50 years). Significant excess nitrogen gas was present in samples from the Public Landing wells, indicating that offshore fresh groundwater at that site had some nitrate when recharged, which was subsequently denitrified in the aquifer. Ammonium isotope and sediment $\mathrm{N}$ isotope data are consistent with previous results from subestuarine groundwater sampled from beneath Indian River Bay in Delaware (Böhlke and Krantz, 2003; Bratton et al., 2004), indicating that organic $\mathrm{N}$ sources in the two estuaries are similar, organic $\mathrm{N}$ mineralization is the source of the ammonium, and that minimal fractionation $(<2 \%)$ takes place during remineralization. Groundwater ages, however, are generally greater than those calculated in the Delaware study. Supporting figures and data tables showing some results of analyses are included in the Supplemental Material, Sections B (Figs. B.1 and B.2) and C (Tables C.1 through C.5).

\subsection{Public Landing site}

\subsubsection{Sediments and salinity}

Consistent with results of previous drilling near Public Landing (Bratton et al., 2004; Manheim et al., 2004), sediment cores from site PL-2003-01 (Fig. 1B) showed that the area is underlain by approximately $1.5 \mathrm{~m}$ of fine-grained Holocene estuarine deposits, over a thin (15-30 cm thick) buried peat (Supplemental Material, Table C.2). Beneath these surficial sediments are fine to medium sands with silt and clay interbeds of the Sinepuxent Formation. Coarser and cleaner sands of the Beaverdam Formation may be present at PL-2003-01 below $14 \mathrm{~m}$ based on the drop in gamma log values at the bottom of the profile (Fig. 2). The gamma log of the onshore well at Public Landing (WO-Ee-18) shows $11 \mathrm{~m}$ of fine sand interbedded with silt (the Sinepuxent Formation) overlying massive coarse sands of the Beaverdam Formation to the bottom of the hole. The upper several meters at this site consist of fill; there are no overlying deposits of Holocene peats or estuarine muds in the section. A thin, fine-grained unit (higher gamma activities) at a depth of $10 \mathrm{~m}$ on land appears to correlate with a thicker offshore unit at 8-9.5 mbsf. The onshore well is only $10 \mathrm{~m}$ from the bay shoreline, but the low EM log values $(<50 \mathrm{mS} / \mathrm{m})$ indicate fresh groundwater over the entire $25-\mathrm{m}$ thickness penetrated by the well.

Porewater salinity at site PL-2003-01 (Fig. 3; Supplemental Material, Table C.3) drops from 28 to 4.5 in the top $64 \mathrm{~cm}$ of sediment and reaches 0 by $3.4 \mathrm{~m}$ in clean medium sand. The groundwater stays 

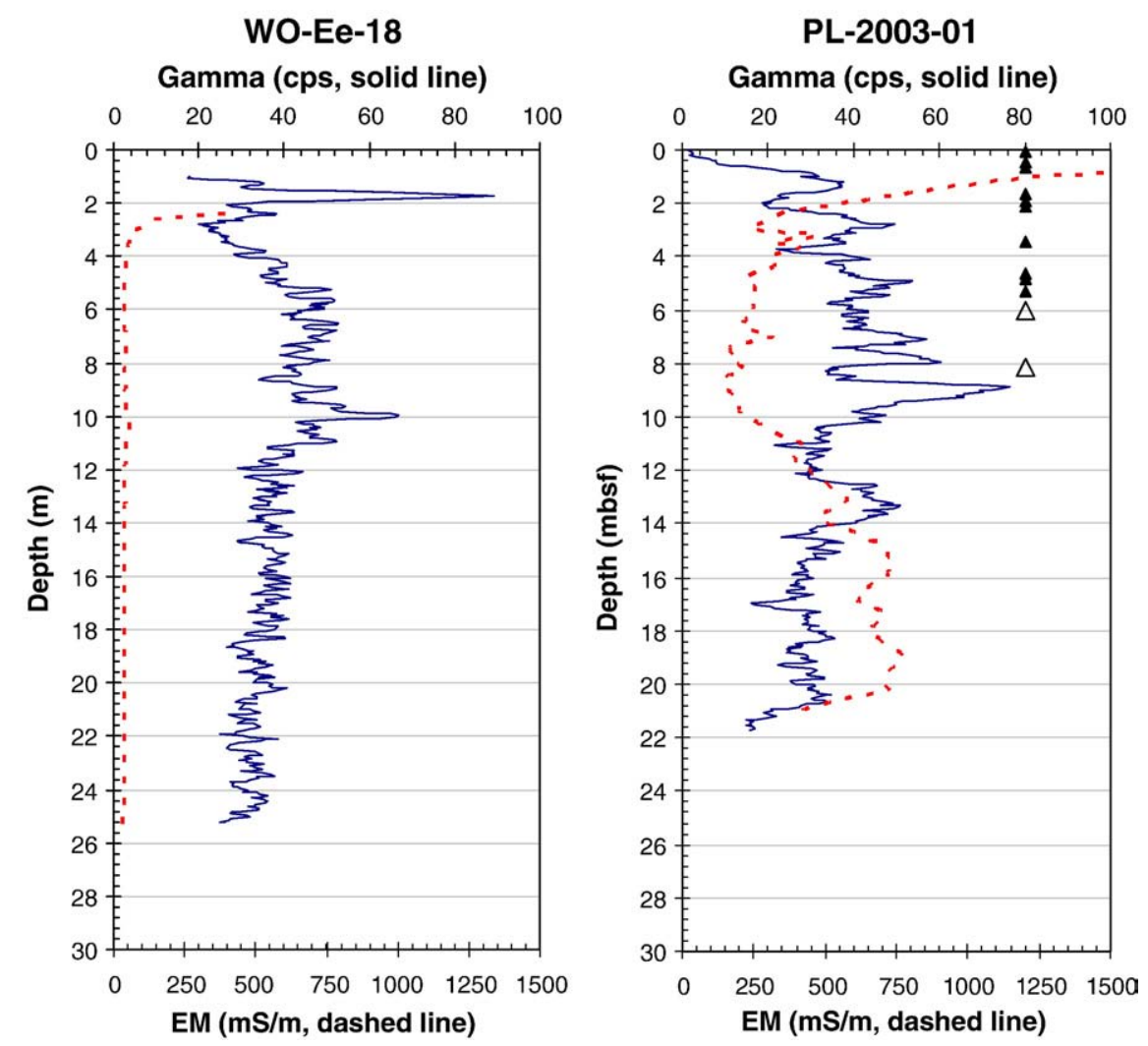

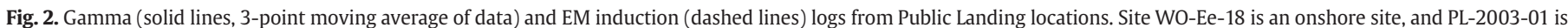

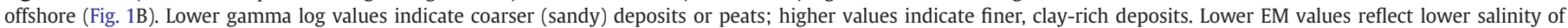

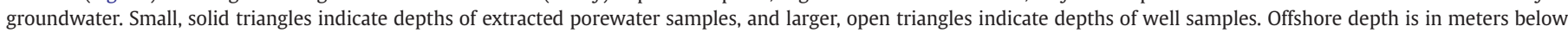
seafloor (mbsf).

fresh or nearly fresh to the maximum depth sampled, $8.1 \mathrm{~m}$, but appears to gradually increase in salinity to about 23 below $10 \mathrm{~m}$, based on the EM log value of about $700 \mathrm{mS} / \mathrm{m}$ (Fig. 2). The EM log also indicates freshening in the last meter of the hole below a depth of $20 \mathrm{~m}$, approximately coincident with an increase in grain size based on the gamma profile (Fig. 2). A positive head of $+10 \mathrm{~cm}$ above the bay surface water height was measured in the 6.0 -m well after sampling and recovery, but this could have been a transient head difference due to tides. Detailed tide stage data that span the measurement period are not available, but the mean tidal range at the Public Landing site is only $16.2 \mathrm{~cm}$, and the spring range is $19.2 \mathrm{~cm}$, as reported by NOAA for this station. The $8.1-\mathrm{m}$ well yielded a head of $+47 \mathrm{~cm}$; the head measured in open casing at a depth of $16.6 \mathrm{~m}$ was similar, $+46 \mathrm{~cm}$. Both of these latter two head differences significantly surpass the tidal range. The shallow, low-permeability units that maintain these head gradients also prevent significant discharge in areas where the heads were measured, except in areas where they may be breached or discontinuous. Similar upward hydraulic gradients (approximately $+60-\mathrm{cm}$ head difference between shallow [4.5-m] and deep [25-m] wells) were measured in the onshore well cluster at the location of well WO-Ee-18 (Dillow et al., 2002). Based on results of previous continuous resistivity surveys, semi-confined fresh groundwater may extend between 1.8 and $2.3 \mathrm{~km}$ offshore along the western margin of Chincoteague Bay (Manheim et al., 2004; Chincoteague Bay lines 4 and $6)$.

\subsubsection{Nutrients}

Nutrient concentrations measured in squeezed porewater and pumped groundwater at the Public Landing site are generally consistent with prior results (Fig. 3) (Bratton et al., 2004). Ammonium concentration maxima of approximately $760 \mu \mathrm{M}$ are present at PL-2003-01 in the estuarine sediments and the peat at $48 \mathrm{~cm}$ and $1.7 \mathrm{~m}$, respectively. Ammonium is present at concentrations less than $15 \mu \mathrm{M}$ below $6 \mathrm{~m}$. Nitrate concentration maxima are present above and below the high ammonium zone, reaching concentrations of almost $200 \mu \mathrm{M}$, but nitrate concentrations also drop to near zero by $6 \mathrm{~m}$. Some of the nitrate measured in squeezed porewater samples from the reducing sediments may be the result of oxidation of ammonium in these small-volume samples during sampling, processing, and preparation for analysis. Phosphate concentrations are generally low, with a shallow maximum of $16.3 \mu \mathrm{M}$ at $48 \mathrm{~cm}$. Ammonium to phosphate ratios of these and other Chincoteague samples range from about 10 to 40 , consistent with mineralized organic matter, which has N:P ratios ranging from Redfield values to higher numbers (Atkinson and Smith, 1983). Silicate concentrations at this site peak at $64 \mathrm{~cm}(780 \mu \mathrm{M})$, drop to $86 \mu \mathrm{M}$ by $4.7 \mathrm{~m}$, and then rise again to the maximum sampling depth $(8.1 \mathrm{~m})$.

There is strong evidence for denitrification in groundwater from depths of both 6.0 and $8.1 \mathrm{~m}$ at PL-2003-01 (Fig. 4). Water from the shallow and deep wells at this site contained approximately 80 and $120 \mu \mathrm{M}$ of excess $\mathrm{N}_{2}$ with $\delta^{15} \mathrm{~N}$ values of total dissolved $\mathrm{N}_{2}$ of 0.96 and $1.09 \%$, respectively (Supplemental Material, Table C.4). These data are consistent with initial nitrate concentrations of 160 and $240 \mu \mathrm{M}$ and initial $\delta^{15} \mathrm{~N}$ values of nitrate on the order of +2 to $+6 \%$.

\subsubsection{Water ages}

Water samples were analyzed for a variety of environmental tracers commonly used for groundwater dating to obtain information about recharge history and to put subestuarine groundwater within a time context relative to agricultural development and fertilizer use trends in surrounding watersheds (Dillow et al., 2002). Age dating summaries and related analytical results for groundwater samples are presented in Table 1 and Table C.4 (Supplemental Material), respectively, and in 

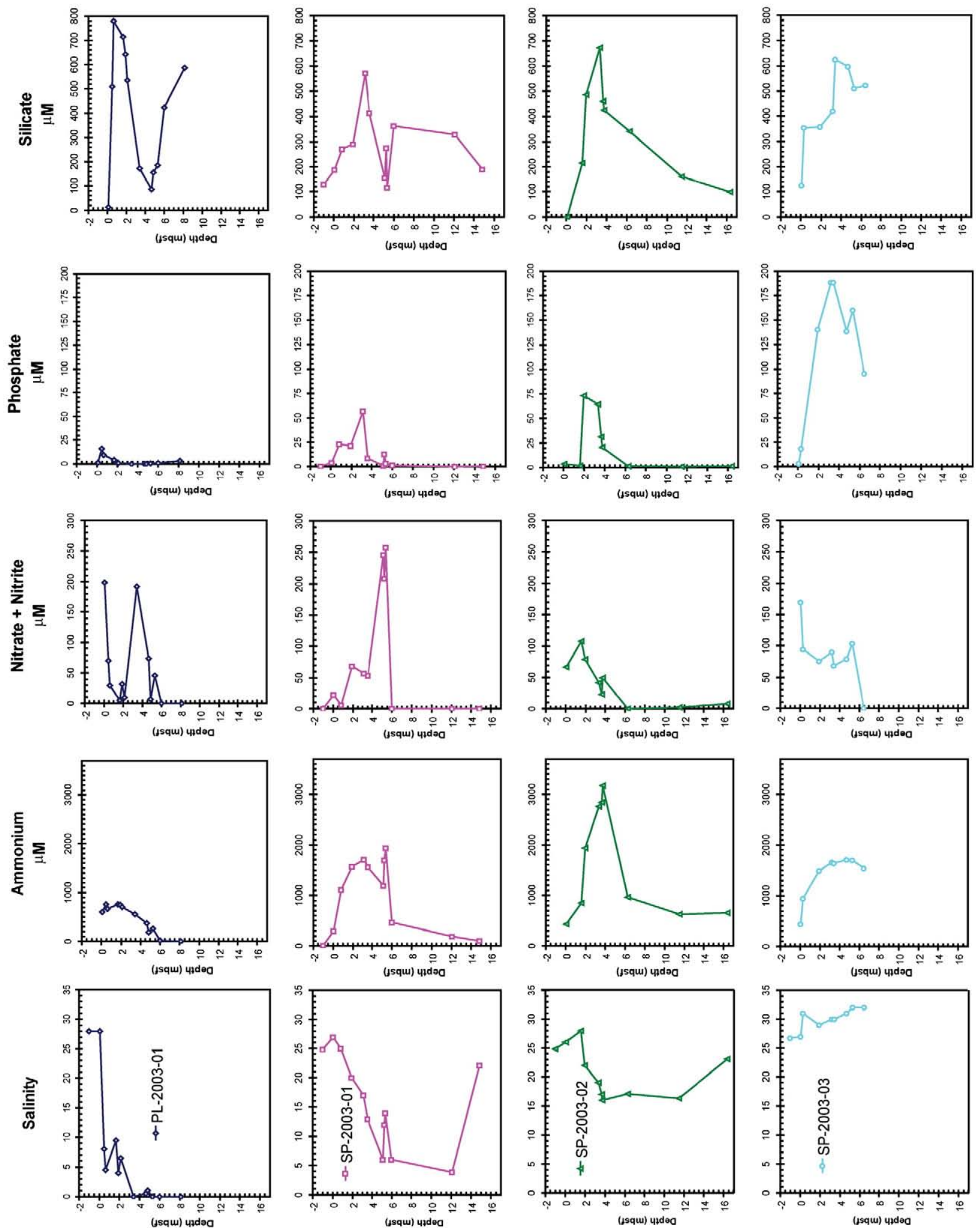

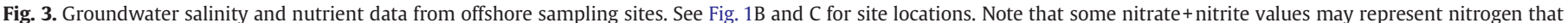

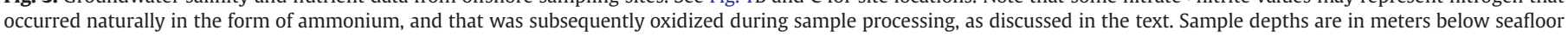
(mbsf).

Figs. 5-7. Both of the Public Landing site samples yielded apparent ${ }^{3} \mathrm{H}-{ }^{3} \mathrm{He}$ ages of around 30 years; the ${ }^{3} \mathrm{H}$ concentrations, however, were less than $0.5 \mathrm{TU}$, indicating that most of the water was more than 50 years old (recharged before 1954, when atmospheric ${ }^{3} \mathrm{H}$ concentrations first exceeded current values as a result of thermonuclear bomb testing). The inconsistency of the apparent ${ }^{3} \mathrm{H}-{ }^{3} \mathrm{He}$ ages and the ${ }^{3} \mathrm{H}$ concentrations for these and other samples is illustrated in Fig. 5. Comparison of multiple tracers indicates that the Public Landing samples probably contained a large fraction (95-100\%) of water greater than 50 years old that is not datable by these methods and a small 
A

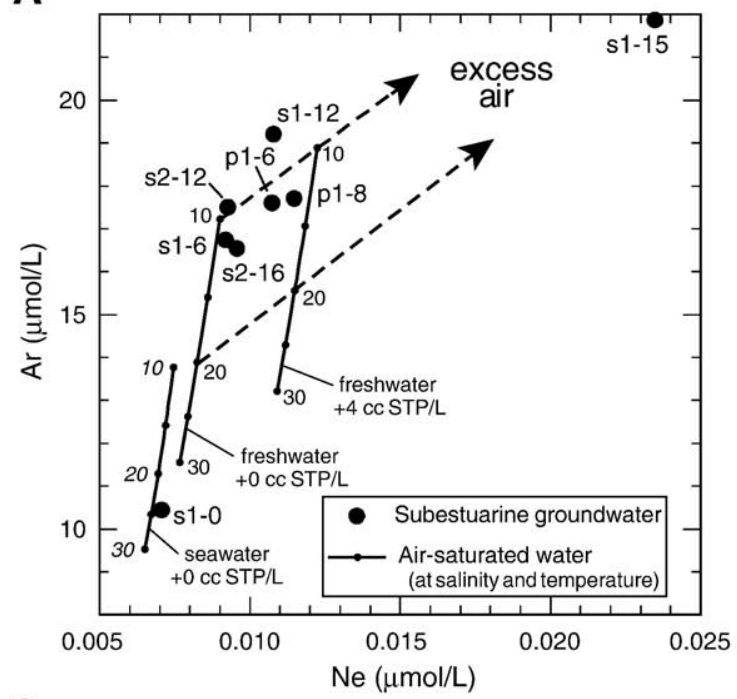

C

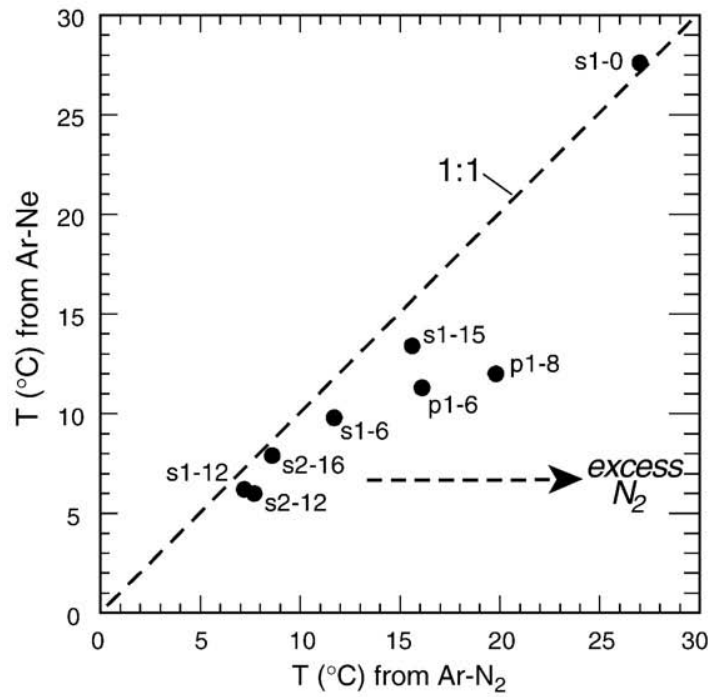

B

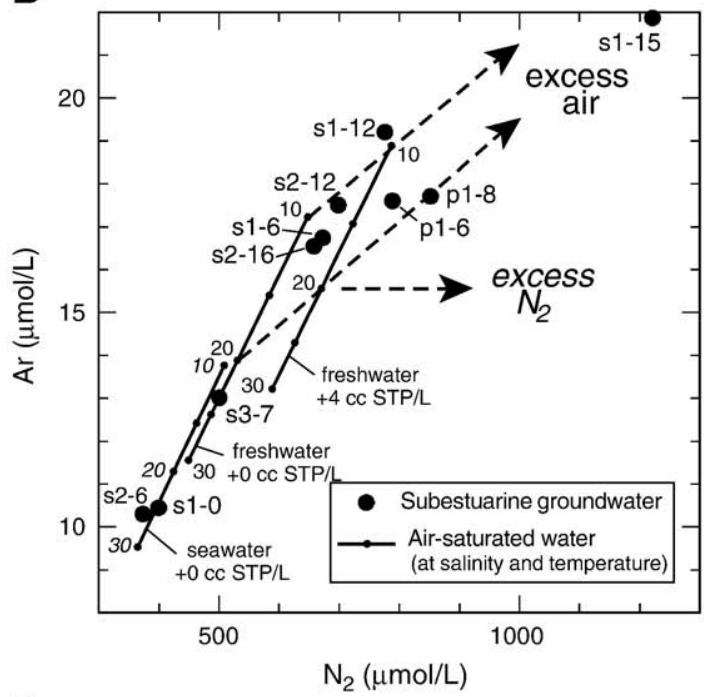

D

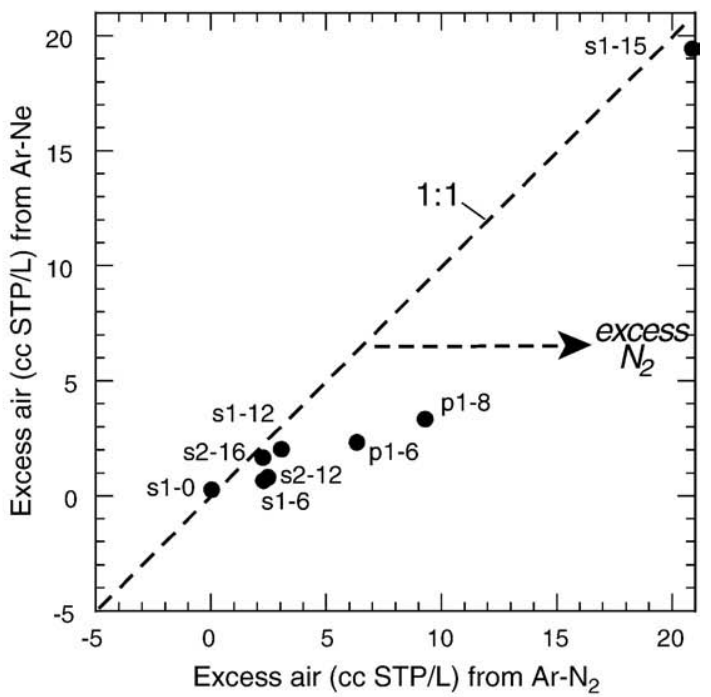

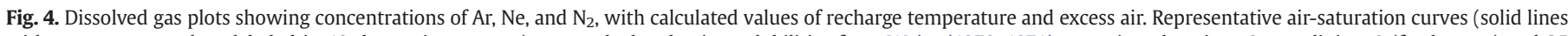

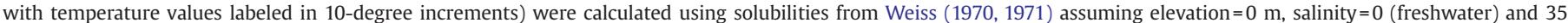

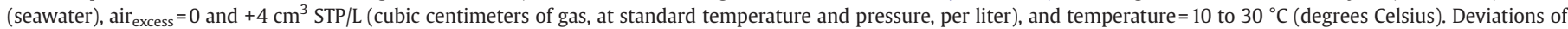

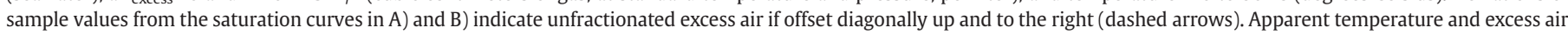

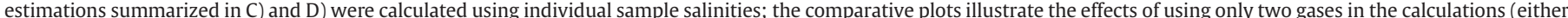

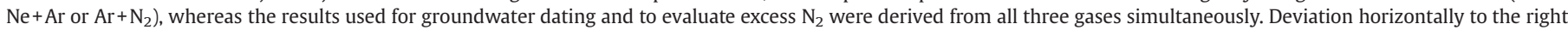

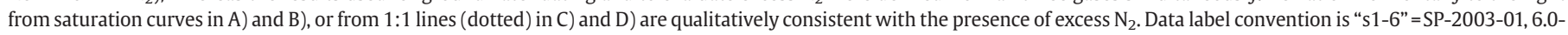
$\mathrm{m}$ depth; "p1-6" =PL-2003-01, 6.0-m depth. Depths on labels are rounded to nearest meter.

fraction of water less than 50 years old $(0-5 \%)$ containing the tracers (Table 1; Fig. 6). In Fig. 6, each curve represents the locus of points that would be consistent with a given conceptual model for the age distribution of the sample over a range of mean ages (Böhlke and Krantz, 2003; Lindsey et al., 2003; Böhlke, 2006). A sample of unmixed groundwater with a single age should plot along the "piston-flow" curve in each case, if the tracer data were reliable and consistent. In general, the Chincoteague groundwater tracer data do not fall on this curve, indicating that apparent recharge dates and ages calculated from ${ }^{3} \mathrm{H}-$ ${ }^{3} \mathrm{He}$ and $\mathrm{SF}_{6}$ are misleading. Instead, most of the data plot near binary mixing curves in which the young component appears to have an age near zero years (Fig. 6). These data indicate that the minor young component in the mixed samples may be modern estuarine surface water that entered the subsurface during the installation of the well. It is possible that another reservoir of shallow young groundwater contributed to these mixtures, but this contribution would be small and difficult to resolve.

\subsection{South Point site}

\subsubsection{Sediments and salinity}

Because Sinepuxent Neck, the peninsula that ends at South Point, has been identified as a late Marine Isotope Stage (MIS) 5 shoreline (Demarest, 1981) formed during a period of higher sea level, it was expected that the submerged offshore area to the south would be underlain by sand. In fact, the sediments encountered were generally finer grained to a depth of approximately $13 \mathrm{~m}$ where Beaverdam Formation sands are present, based on gamma logs (Fig. 8) and some sediment core samples (Supplemental Material, Table C.2). The top $0.3 \mathrm{~m}$ or less of offshore deposits consists of a veneer of recent tidallytransported sands at the SP-2003-01 and -02 sites, with sandier sediment up to $1.5-\mathrm{m}$ thick at the surface at SP-2003-03 (these are likely derived from flood-tidal delta deposits associated with the former Sinepuxent Inlet, which closed in 1818, and other former inlets). This surficial sand is underlain by estuarine silt and clay to 

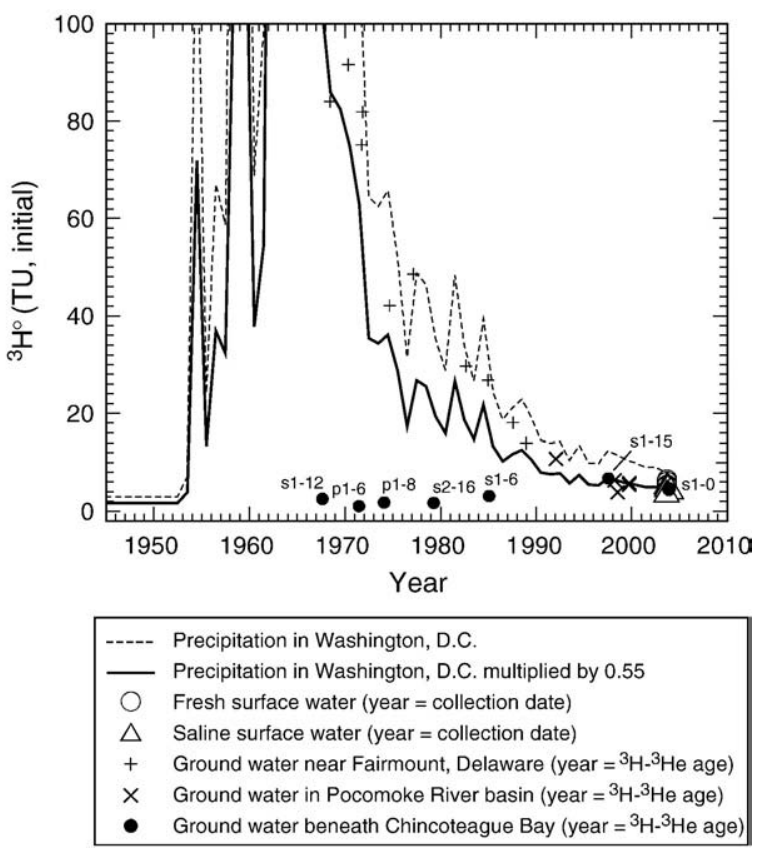

Fig. 5. Documented and inferred values of initial tritium $\left({ }^{3} \mathrm{H}^{\circ}\right)$ concentrations in precipitation and recharging ground water, compared with measured and calculated values for subestuarine groundwater samples (Supplemental Material, Table C.4). Shown for comparison are IAEA data for Washington, D.C. precipitation. The hypothetical curve for the Maryland coast was drawn by assuming that it was correlated with the Washington, D.C. curve but systematically lower (multiplied by 0.55 ), as indicated by comparative analyses of modern surface waters (Böhlke and Krantz, 2003; this study). Plotted ${ }^{3} \mathrm{H}$ values of surface waters are the measured values at the time of sampling in August 2003. Data label convention is "s1-6" =SP-2003-01, 6.0-m depth; "p1-6" = PL-2003-01, 6.0-m depth. Depths on labels are rounded to nearest meter. Note: Apparent ${ }^{3} \mathrm{H}^{3}{ }^{3} \mathrm{He}$ "ages" for Chincoteague Bay groundwater samples are not consistent with their ${ }^{3} \mathrm{H}$ concentrations because of mixing, and therefore are misleading (see text and Fig. 6).

depths of about $6 \mathrm{~m}$, with a thin peat ( $\sim 0.3 \mathrm{~m}$ thick) present 2.0 to $3.5 \mathrm{~m}$ below the sediment surface (recovered in cores from SP-200301 and -02; Supplemental Material, Table C.2; inferred from gamma logs at SP-2003-3, Fig. 8). The peat and overlying estuarine sediments are interpreted as Holocene. The underlying fine sediments also may be Holocene age, but could be older. A sandier zone is present at a depth of $6 \mathrm{~m}$ that decreases in grain size downward to $10 \mathrm{~m}$, then becomes coarser, gradually at first, and then sharply at the transition to the Beaverdam sands at $13 \mathrm{~m}$. This sandier zone at 6-m depth is not as well developed at the site nearest to shore, SP-2003-01.

At site SP-2003-01, $800 \mathrm{~m}$ from shore (Fig. 1C), lower-salinity groundwater (6-14) is present from 3.5 to $13 \mathrm{~m}$ between the peat and the 13-m sand (Supplemental Material, Table C.2), with saltier water above and below based on the EM log (Fig. 8) and samples of porewater and well water (Fig. 3; Supplemental Material, Table C.3). This discrete low-salinity zone appears to be present at the SP-2003-2 site as well (1.7 km offshore), but is slightly deeper and somewhat saltier (16-17). The EM logs from the SP-2003-3 site indicate that salinity in the upper $6 \mathrm{~m}$ of sediment is higher than at the other South Point sites, but decreases gradually and irregularly with depth to a value comparable to the deepest measurements at the sites closer to shore. Well and porewater samples indicate that salinity is as high as 32 at $6.5 \mathrm{~m}$ depth. Significantly freshened water is not present at depths of less than $22 \mathrm{~m}$ at the most distant site from shore $(2.3 \mathrm{~km})$ in this transect.

\subsubsection{Nutrients}

Nutrient concentrations in groundwater from the South Point site (Fig. 3; Supplemental Material, Table C.3) are generally higher than those at the Public Landing site. Concentrations of all nutrients peak at depths of about 3 to $4 \mathrm{~m}$ at all three sites, around the depth of the buried peat layer. The ammonium concentration peaks at 1700 to $1900 \mu \mathrm{M}$ at SP2003-01 and SP-2003-03, and at 3200 $\mu \mathrm{M}$ at SP-2003-02. Ammonium concentrations drop to less than $1000 \mu \mathrm{M}$ below $6 \mathrm{~m}$ at SP-2003-01 and -03. Nitrate concentration maxima are present above the high ammonium zone at SP-2003-02 $(110 \mu \mathrm{M})$, below the high ammonium zone at SP-2003-01 $(260 \mu \mathrm{M})$, and possibly above and below this zone at SP-2003-03 (170 and $100 \mu \mathrm{M}$, respectively). As mentioned previously, nitrate concentrations in some of the porewater samples are suspect due to the reducing nature of these sediments and the possibility of oxidation during core processing. Concentrations of nitrate at all three sites are at or near detection limits below $6 \mathrm{~m}$. Phosphate concentrations peak at 55 to $75 \mu \mathrm{M}$ in SP-2003-01 and -02, but have a significantly higher maximum of about $190 \mu \mathrm{M}$ at SP-2003-03, consistent with the presence of more organic matter and less iron oxide to adsorb phosphate in the upper few meters of these finegrained, saline, reducing sediments (Rozan et al., 2002). Silicate concentrations peak in the same range, 550 to $670 \mu \mathrm{M}$, at all three sites.

Little or no evidence of denitrification (excess $\mathrm{N}_{2}$ or high $\delta^{15} \mathrm{~N}$ of $\mathrm{N}_{2}$; Fig. 4; Supplemental Material, Table C.4) was seen in the groundwater samples from South Point. Three of the samples had calculated concentrations of excess $\mathrm{N}_{2}$ of around $20-30 \mu \mathrm{M}$ and $\delta^{15} \mathrm{~N}$ of total $\mathrm{N}_{2}$ of $+0.9 \%$ o (SP-2003-01 at $6.0 \mathrm{~m}$; SP-2003-02 at $6.3 \mathrm{~m}$ and $11.5 \mathrm{~m}$ ), whereas some of the other samples appeared slightly more like air-saturated water (SP-2003-02 at $16.4 \mathrm{~m}$, and SP-2003-03 at $6.5 \mathrm{~m}$ ). The differences in the amounts of excess $\mathrm{N}_{2}$ among these samples are considered to be near the limit of detection for the sampling and analytical methods employed. A large amount of excess air precluded calculation of excess $\mathrm{N}_{2}$ in the sample from SP-2003-01 collected at $14.8 \mathrm{~m}$. An anomalously high $\delta^{15} \mathrm{~N}_{2}(+1.2 \%$ o) in the $6.3-\mathrm{m}$ sample from SP-2003-02 was associated with anomalously low gas concentrations and a low calculated value of excess $\mathrm{N}_{2}$, and may have been affected by degassing or other artifacts related to the high $\mathrm{CH}_{4}$ concentration at that site and depth. Relatively high methane concentrations $(\sim 170-260 \mu \mathrm{M})$ measured in shallow samples from SP-2003-01 (6.0 m) and SP-2003-02 (6.3 m) are consistent with anoxic breakdown of organic matter in estuarine sediments and peats at these sites, which also would release ammonium. High methane concentrations were not observed at the SP-2003-03 site, which may be a result of the higher porewater salinity and dominance of sulfate reduction over methanogenesis. Low methane at the Public Landing site in the low-salinity groundwater plume indicates little interaction with the organic-rich sediments and porewater above.

Table 1

Summary of groundwater age interpretations

\begin{tabular}{|c|c|}
\hline Sample site & Age summary \\
\hline $\begin{array}{l}\text { L-2003-01, } \\
6.0 \mathrm{~m}\end{array}$ & $\begin{array}{l}{ }^{3} \mathrm{H},{ }^{3} \mathrm{He} \text {, and } \mathrm{SF}_{6} \text { indicate mixture of } 95-100 \% \text { pre- } 1954 \text { and } 0-5 \% \text { zero age } \\
\text { water; CFCs slightly elevated, possible contamination }\end{array}$ \\
\hline $\begin{array}{l}\text { PL-2003-01, } \\
8.1 \mathrm{~m}\end{array}$ & $\begin{array}{l}{ }^{3} \mathrm{H} \text { and }{ }^{3} \mathrm{He} \text { indicate mixture of } 95-100 \% \text { pre- } 1954 \text { and } 0-5 \% \text { zero age } \\
\text { water; } \mathrm{SF}_{6} \text { and CFCs indicate more young water or possible } \\
\text { contamination; CFC ratios support contamination }\end{array}$ \\
\hline $\begin{array}{l}\text { SP-2003-01, } \\
\quad 6.0 \mathrm{~m}\end{array}$ & $\begin{array}{l}{ }^{3} \mathrm{H},{ }^{3} \mathrm{He}, \mathrm{SF}_{6} \text {, and CFCs all indicate mixture of } 80-85 \% \text { old (pre-tracer) and } \\
15-20 \% \text { zero age water; high methane }\end{array}$ \\
\hline $\begin{array}{l}\text { SP-2003-01, } \\
12.1 \mathrm{~m}\end{array}$ & $\begin{array}{l}{ }^{3} \mathrm{H},{ }^{3} \mathrm{He}, \mathrm{SF}_{6} \text {, and } \mathrm{CFC} 113 \text { all indicate mixture of } 90-95 \% \text { old (pre-tracer) } \\
\text { and } 5-10 \% \text { zero age water; possibly minor excess CFC11 and CFC12 from } \\
\text { contamination }\end{array}$ \\
\hline $\begin{array}{l}\text { SP-2003-01, } \\
14.8 \mathrm{~m}\end{array}$ & $\begin{array}{l}{ }^{3} \mathrm{H},{ }^{3} \mathrm{He}, \mathrm{SF}_{6} \text {, and CFCs all indicate young water }(0-30 \text { years), but } \\
\text { uncertainties are high due to large amount of excess air }\end{array}$ \\
\hline $\begin{array}{l}\text { SP-2003-02, } \\
\quad 6.3 \mathrm{~m}\end{array}$ & $\begin{array}{l}{ }^{3} \mathrm{H} \text { indicates almost all pre-1954 water; } \mathrm{SF}_{6} \text { and CFC data indicate minor } \\
\text { contamination; He-Ne analysis failed (possible high } \mathrm{He} \text { ); high methane }\end{array}$ \\
\hline $\begin{array}{l}\text { SP-2003-02, } \\
11.5 \mathrm{~m}\end{array}$ & ${ }^{3} \mathrm{H},{ }^{3} \mathrm{He}, \mathrm{SF}_{6}$, and $\mathrm{CFC}$ all indicate pre- 1954 water \\
\hline $\begin{array}{l}\text { SP-2003-02, } \\
16.4 \mathrm{~m}\end{array}$ & $\begin{array}{l}{ }^{3} \mathrm{H},{ }^{3} \mathrm{He} \text {, and } \mathrm{SF}_{6} \text { all indicate about } 90 \% \text { old (pre-tracer) and } 10 \% \text { young } \\
\text { water; CFCs near zero, possibly degraded }\end{array}$ \\
\hline $\begin{array}{l}\text { SP-2003-03, } \\
6.5 \mathrm{~m}\end{array}$ & $\begin{array}{l}{ }^{3} \mathrm{H} \text { and CFCs consistent with about } 90 \% \text { old (pre-tracer) and } 10 \% \text { young } \\
\text { water; } \mathrm{SF}_{6} \text { slightly elevated; He-Ne analysis failed (possible high } \mathrm{He} \text { ) }\end{array}$ \\
\hline
\end{tabular}

Notes:

See Supplemental Material, Table C.4 for data. 
A

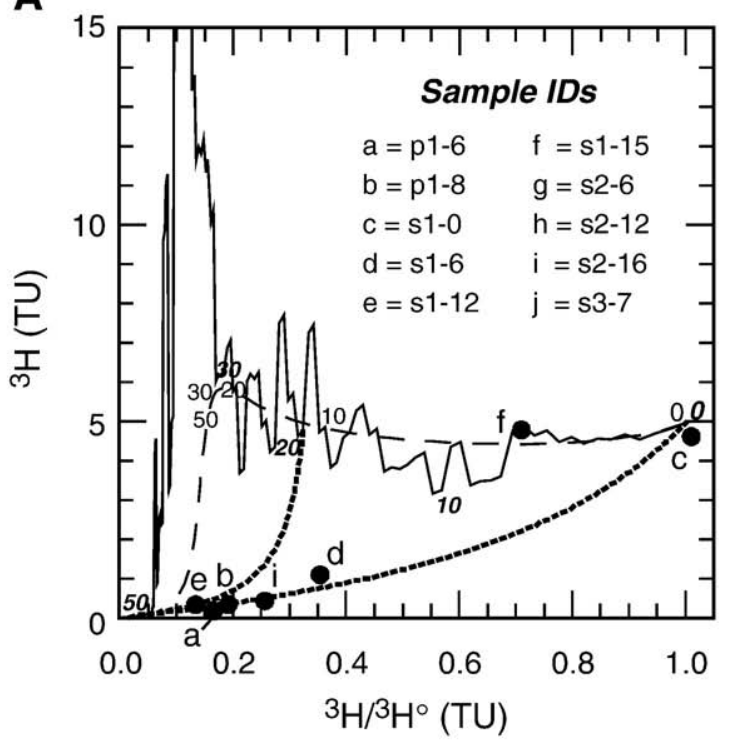

B

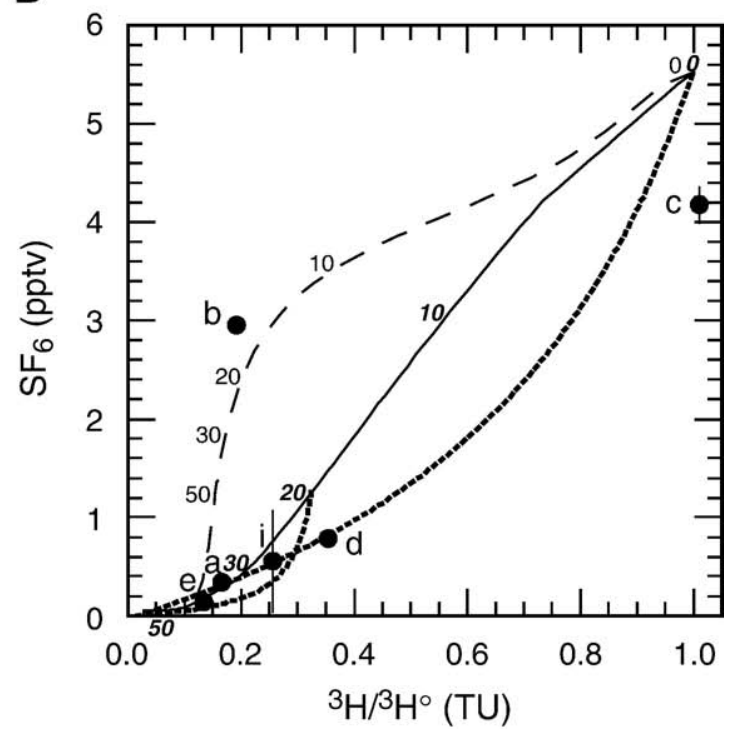

Fig. 6. Cross-plots of $(A){ }^{3} \mathrm{H}$ and (B) $\mathrm{SF}_{6}$ versus the ${ }^{3} \mathrm{H} /{ }^{3} \mathrm{H}^{\circ}$ ratio $\left({ }^{3} \mathrm{H}^{\circ}={ }^{3} \mathrm{H}^{3} \mathrm{He}_{\text {tritiogenic }}\right)$. Data label convention is "s1-6" =SP-2003-01, 6.0-m depth; "p1-6" = PL-2003-01, 6.0-m depth. Depths on labels are rounded to nearest meter. Curves representing theoretical values consistent with various modeled modes of groundwater flow and mixing (plotted with program Tracermodel1 for samples collected in 2003; Böhlke (2006)) are shown for piston flow (no mixing, solid line), exponential mixing (long dashes), or bimodal mixing (short dashes; old endmembers are pre-tracer and young endmembers are either 0 or 20 years old). Selected mean ages are indicated on the exponential model curves (normal font) and discrete ages are indicated on the piston-flow curves (bold italic font).

\subsubsection{Water ages}

The surface water sample from the South Point offshore site (SP2003-01) yielded results consistent with zero age for the ${ }^{3} \mathrm{H}$ and ${ }^{3} \mathrm{He}$ data (Supplemental Material, Tables C. 4 and C.5; Figs. 5 and 6). Minor deficiencies were observed in $\mathrm{SF}_{6}$ and $\mathrm{CFC} 12$, possibly related to minor disequilibrium caused by dynamic temperature variations or bubble stripping. CFC11 and CFC113 were depleted significantly, possibly from degradation during storage, which is commonly observed in surface water samples (Plummer et al., 1998). The concentrations of the major dissolved gases are consistent with the measured temperature, with little or no excess air or excess $\mathrm{N}_{2}$ (Fig. 4).

Age dating summaries and related analytical results for groundwater samples from the SP-2003 sites are presented in Tables 1 and
C.4 (Supplemental Material), respectively, and Figs. 5-7. Most of the data indicate pre-bomb water (>50 years old), or mixtures of $80-95 \%$ pre-bomb water with $5-20 \%$ post-bomb water. As at the Public Landing sites, these mixtures appear to be bimodal with the younger endmembers near zero age, possibly indicating minor contamination of the groundwater samples by modern surface water. The deep saline sample from beneath the freshened layer at SP-2003-01 $(14.8 \mathrm{~m}$, salinity=23.5) appears to be anomalously young on the basis of several different tracers. Samples from this well contained unusually large amounts of excess air, which may have been introduced accidentally during difficult drilling of the last $2 \mathrm{~m}$ of the hole or during development of the well. This excess air results in large uncertainties in gas-based ages, but the modern concentration of ${ }^{3} \mathrm{H}$ supports the interpretation that the groundwater at this depth may have been relatively young. Although the age of groundwater in this well is poorly defined, the possible occurrence of deep, young saline groundwater beneath fresher water in subestuarine systems would not be unprecedented. Evidence for such a situation was reported from beneath Indian River Bay, Delaware, indicating possible vigorous
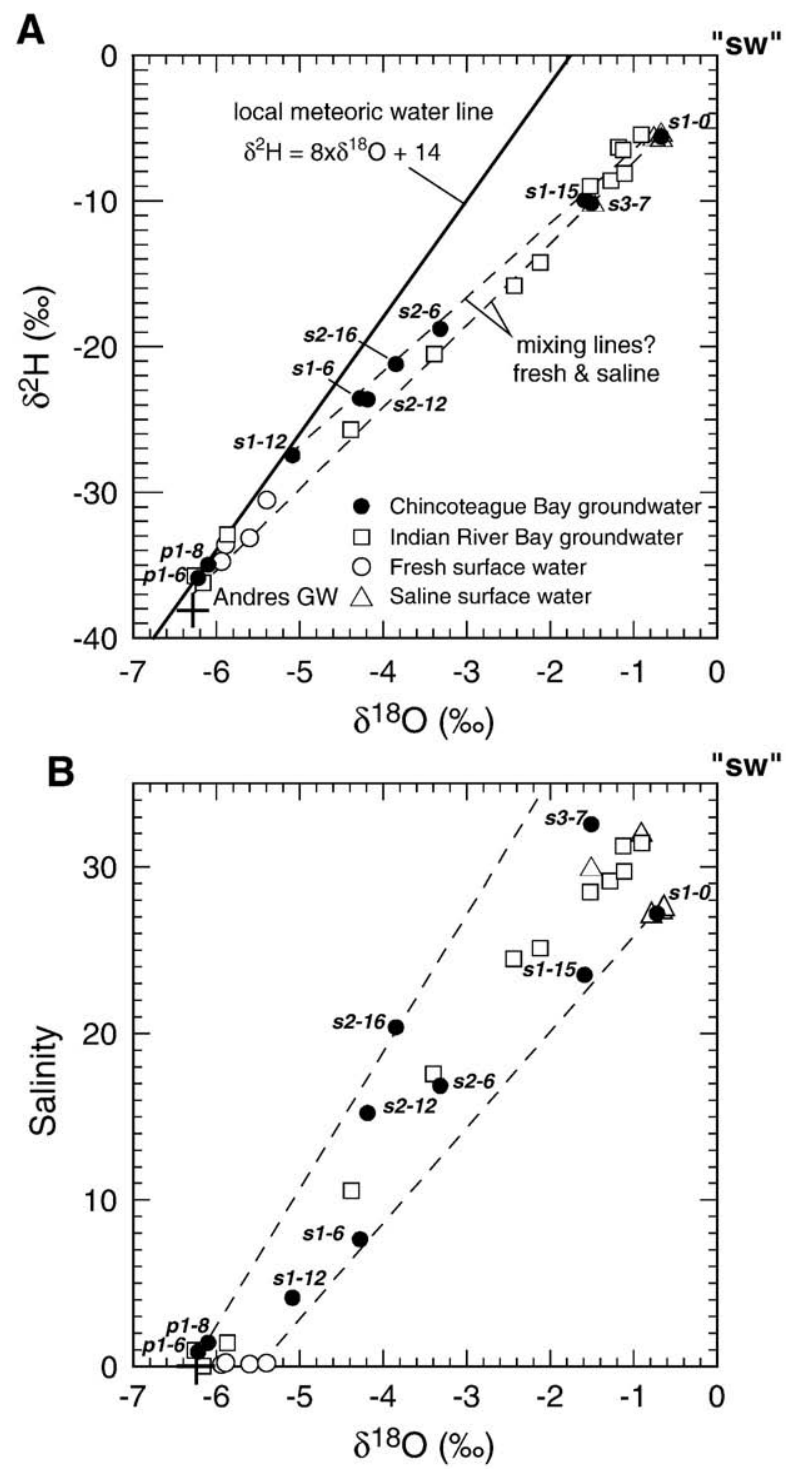

Fig. 7. $\mathrm{H}$ and $\mathrm{O}$ isotopes and salinities for water samples. Symbol labeled "sw" indicates values for standard seawater. Symbol labeled "Andres GW" indicates average values for the coastal watershed near Indian River Bay, Delaware (Andres, 1991). Data from Indian River Bay are from Böhlke and Krantz (2003). Dashed lines indicate possible mixing lines between fresh meteoric water and saline water. 

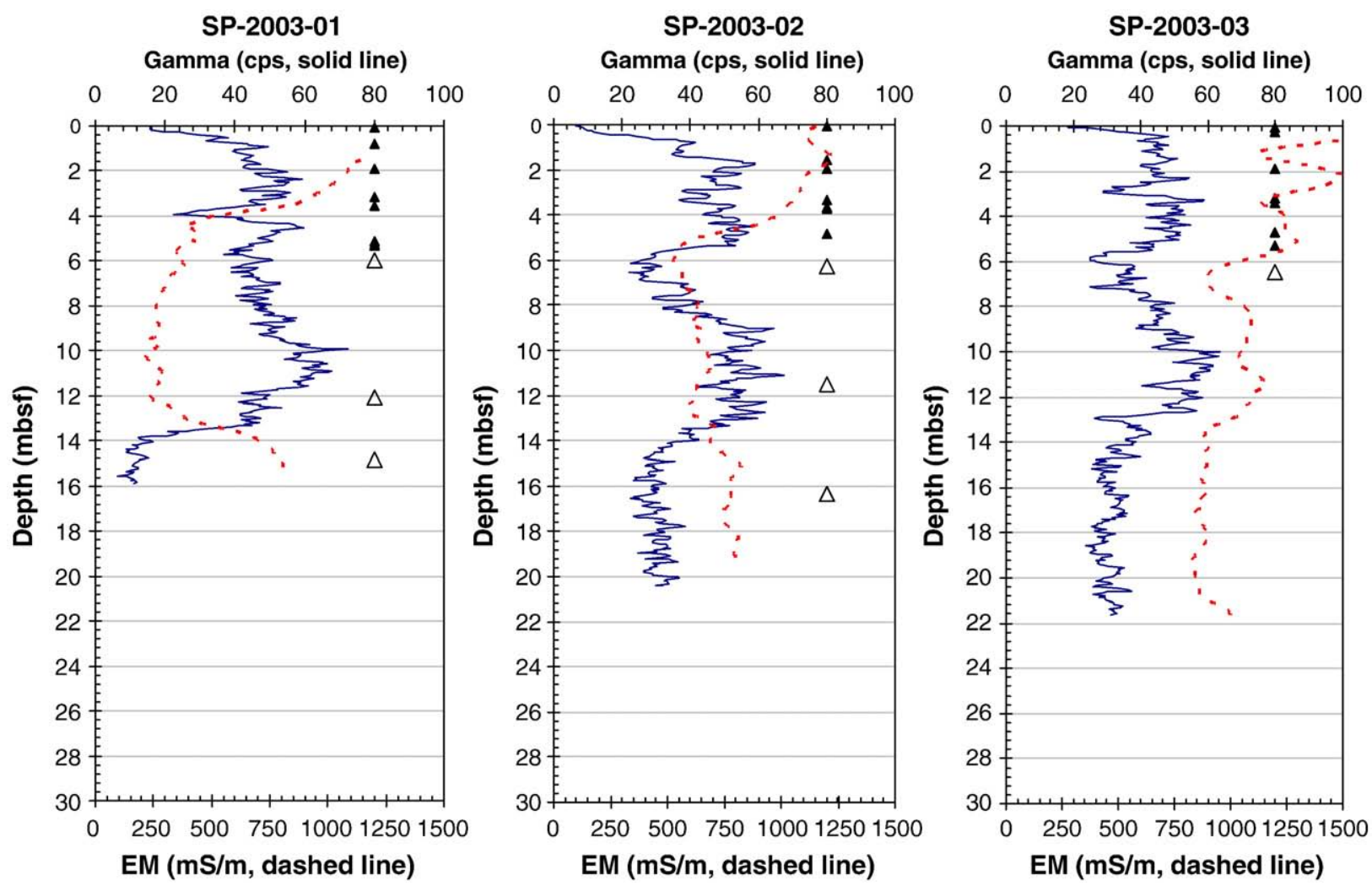

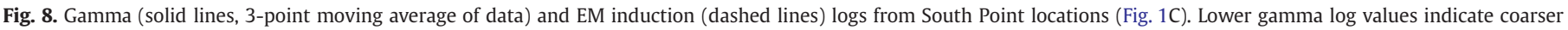

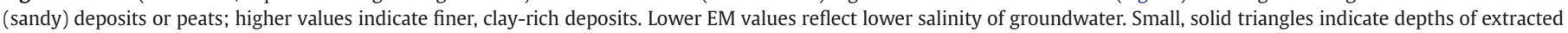
porewater samples, and larger, open triangles indicate depths of well samples.

circulation of saline groundwater around offshore fresh-water plumes (Böhlke and Krantz, 2003; Bratton et al., 2004).

\subsection{Assateague Island sites}

Data from Assateague Island wells bracket the groundwater flow system of Chincoteague Bay on the oceanward side. The EM and gamma logs from the sites on Assateague Island (Supplemental Material, Fig. B.1) show variable stratigraphy at the northern and southern sites, and generally sandier sediments at the middle site (WO-Ef-26). The northern Assateague Island well, WO-Dg-23, penetrates approximately $5 \mathrm{~m}$ of sand, with interbedded sands and finegrained deposits extending down to $24 \mathrm{~m}$, and then a return to sand (likely the Beaverdam Formation). The surficial freshwater lens extends to the base of the upper sands $(5 \mathrm{~m})$. A brackish zone is present from 5 to $13 \mathrm{~m}$ based on EM log data and samples from a 4.6-m well in the cluster at this site (WO-Dg-25; Dillow et al., 2002). Salinity then returns to near zero for the remainder of the hole, indicating that deeper fresh water that originally recharged on the mainland likely flows beneath both Sinepuxent Bay and northern Assateague Island, consistent with interpretations by Dillow et al. (2002). The middle Assateague site, at the location of well WO-Ef-26, is generally sandy to a depth of $15 \mathrm{~m}$, followed by a 3-m bed of silt and clay, and finally a return to sand at $18 \mathrm{~m}$ that generally fines downward to about $30 \mathrm{~m}$. The $15 \mathrm{~m}$ of sand at this site likely represents the fill of a former inlet channel that cut across the island prior to the mid 1800s. The upper $6 \mathrm{~m}$ of this sand contains fresh groundwater. The salinity then increases to a hypersaline maximum around $17 \mathrm{~m}$ near the top of the fine-grained unit. Samples with more than twice the salinity of seawater (77) were collected previously from a well at this site screened at $11 \mathrm{~m}$ (WO-Ef-27, Dillow et al., 2002). Groundwater salinity drops back to brackish levels below the fine-grained unit (>18 m) at this site. Gamma logs from the southern Assateague well, located at
Valentine's Lodge in the Green Run area, indicate variable stratigraphy similar to the northern site. The freshwater lens, however, is only $2 \mathrm{~m}$ thick, and is underlain entirely by brackish water to the maximum depth logged $(21 \mathrm{~m})$.

\section{Discussion}

\subsection{Relationships between stratigraphy, salinity, and groundwater flow}

The salinity of the groundwater beneath Chincoteague Bay generally is lower than might have been anticipated from models that assume geological homogeneity and simple Ghyben-Herzberg relationships between fresh and saline groundwater in coastal areas. The patterns observed, however, are consistent with results of continuous resistivity profiling (CRP) surveys conducted previously (Manheim et al., 2004). The CRP method distinguishes the electrical resistivity contrast between sediments saturated with saline porewater (low resistivity) versus low-salinity porewater (high resistivity), using a floating cable equipped with electrodes that create and measure the intensity of an electrical field generated in the watersediment system. Significant uncertainties about the exact style, locations, and total fluxes of subestuarine groundwater into Chincoteague Bay remain; a future study using seepage meters located in areas of likely discharge based on additional high-resolution CRP surveying and potentially aerial infrared surveying would be a logical next step in resolving these issues.

The Public Landing sampling and downhole geophysical results confirm the presence of fresh groundwater that may extend up to $2.3 \mathrm{~km}$ offshore from the west side of Chincoteague Bay (Fig. 9), as inferred from high-resistivity zones in two shore-perpendicular CRP survey lines from this area (Figs. 9 and 10 of Manheim et al., 2004). As described above, the fresh zone is about $8 \mathrm{~m}$ thick. The peat and estuarine silt and clay deposited beneath the bay during the Holocene 

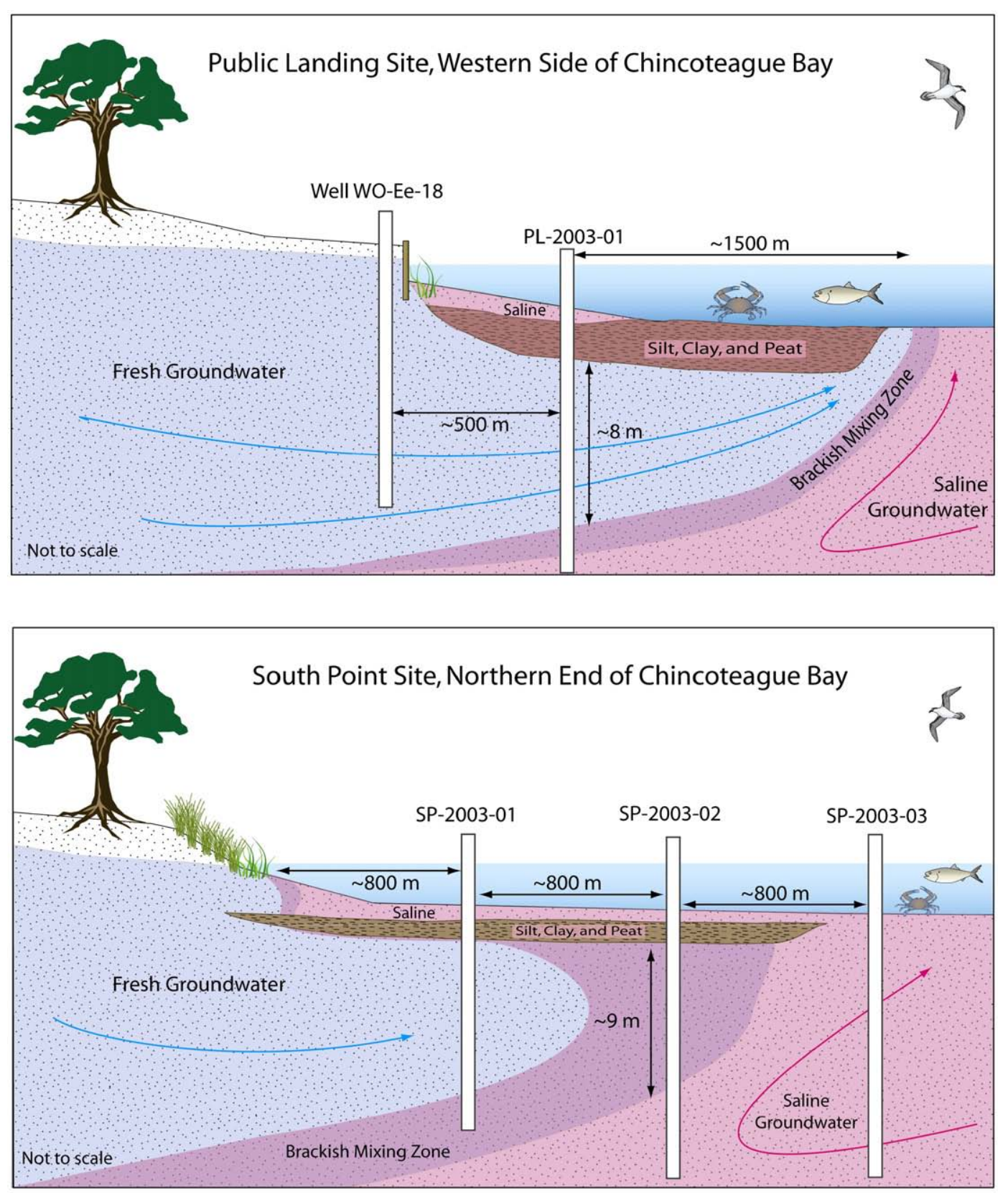

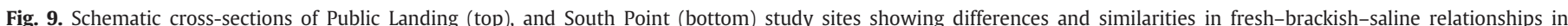

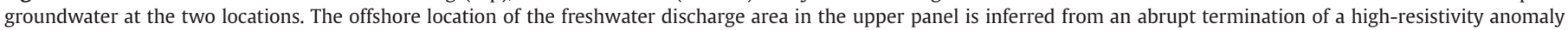
extending out from the mainland in the continuous resistivity profile collected near this site (Manheim et al., 2004).

transgression, and deeper Pleistocene units that likely extend inland of the shoreline, are sufficiently impermeable in the vertical direction to produce heads above sea level of approximately $50 \mathrm{~cm}$ at a depth of $8 \mathrm{~m}$ below the sediment surface, which is more than double the maximum tidal range at this location. This may be partially due to the efficiency of onshore recharge through a sandy terrace above a shoreparallel paleoshoreline scarp that is present about $2.5 \mathrm{~km}$ inland of this side of Chincoteague Bay. The terrace has an elevation of approximately $12 \mathrm{~m}$ above sea level.

The CRP surveys indicate that the geometry and the salinity contrast of the subestuarine flow system are maintained in a fairly constant configuration out to the edge of the confining unit, at which point the confining unit appears to terminate abruptly (Manheim et al., 2004), allowing the fresh groundwater to discharge upward into the estuary. The exact nature of this discharge is unclear but may take the form of a line of discrete springs, a band of more diffuse brackish advection reflecting mixing with circulated surface water, or a combination of the two. Future field studies, and possibly variabledensity flow modeling, will be necessary to constrain the style and total magnitude of this discharge into Chincoteague Bay. Although the flow system appears to be generally continuous along the western shore of the bay, based on the limited available data, shore-parallel CRP data indicate that incised and buried paleochannels of drowned tidal creeks may create linear discharge zones oriented approximately perpendicular to the shore that locally distort this sheet-like flow system. This flow system may be evolving as rising sea levels continue to inundate the extensive fringing marsh along much of the western shore of the modern bay.

The South Point results show a similar freshened flow system beneath this part of the bay (Figs. 3, 8, and 9), but reflect the influence of a different shoreline geometry and less relief in the recharge area. The confining peat combined with estuarine silt and clay are present 
here as at Public Landing, but because the local recharge area is a low, narrow peninsula, less fresh water is available for the subestuarine flow system. The result is a freshened groundwater layer of similar thickness to that seen at Public Landing, but potentially with higher salinity (6 at $800 \mathrm{~m}$ offshore, 16 at $1700 \mathrm{~m}$ ), which could indicate less vigorous offshore flow and relatively more mixing with circulating surface water beneath the bay. Insufficient data are available for the portion of the Public Landing plume that lies farther offshore than the single site sampled (PL-2003-01) to make a direct comparison possible. By $2.3 \mathrm{~km}$ offshore, the groundwater at South Point is as salty, or more salty, than the overlying surface water (Figs. 3, 8, and 9), as a result of more permeable shallow sediments that permit downward flow of estuarine water into the subsurface. The fresher subestuarine water observed closer to shore likely enters the bay offshore as diffuse, brackish discharge, after gradually mixing with saline water in the subsurface.

The deep (>14 $\mathrm{m}$ below sea level), fresh groundwater flow system in the Beaverdam Formation sand in the northern Chincoteague Bay area near South Point appears to be isolated from the surface waters, completely underflowing Sinepuxent Bay and Assateague Island, and presumably discharging beneath the Atlantic Ocean. This is indicated by the EM log from the on-land WO-Dg-23 well (Supplemental Material, Fig. B.1). Brackish water between the surficial fresh lens on the island and the deep fresh zone may reflect underflow from either the ocean or the bay, with some dilution by fresher water above and, in the northern part of the island, below. Investigations in other locations have indicated that higher average water levels on the ocean side of some barrier islands produced by wave run-up tend to drive salt water from the ocean side to the bay side of such islands (Vacher, 1988). The anomalous brine at the WO-Ef-26 site on Assateague Island may reflect a perched pool of high-salinity water derived by evaporation and infiltration from overwash ponds, and settling into a sandy inlet channel fill incised into a low-permeability unit. Alternatively, the brine could be generated in situ by ongoing dissolution of localized salt pan deposits laid down during a lower stand of sea level and subsequently buried. Beneath the brine, EM logs indicate that the salinity of the groundwater is typical of underflowing brackish water elsewhere. Cross-barrier groundwater flow in this and other systems merits further study (Niencheski et al., 2007).

\subsection{Sources and ages of fresh and saline groundwaters}

Correlated variations in $\delta^{2} \mathrm{H}, \delta^{18} \mathrm{O}$, and salinity (Fig. 7) in the offshore groundwaters are roughly consistent with mixtures of fresh and saline endmembers. The correlation between $\delta^{2} \mathrm{H}$ and $\delta^{18} \mathrm{O}$ in the Chincoteague samples is similar to that observed in nearby Indian River Bay, Delaware (Böhlke and Krantz, 2003; Fig. 1); the relationship between salinity and $\delta^{18} \mathrm{O}$, however, exhibits more variability in Chincoteague Bay samples than in those from Indian River Bay. Induced mixing of young surface water into the sampled wells indicated by the other environmental tracers may have shifted some of these data slightly toward the modern estuarine values, but would not produce the degree of scatter shown (Fig. 7B). Analyses of subaliquots from bottles collected at various times during the sampling period at each well yielded identical results, indicating that the scatter of the data is not a result of changes in the water masses being pumped during sampling or of storage problems after sampling. Therefore, in contrast to Indian River Bay, it must be concluded that the Chincoteague groundwaters were not simple mixtures of two uniform endmembers. Processes that may have complicated these relations include 1) seasonal variations of meteoric water entering the estuary, and 2) evaporation of either fresh or saline surface waters prior to recharge. The second process is likely considering that Chincoteague Bay is quite shallow with a long residence time (63 days by calculations of Pritchard (1960)) and restricted water exchange with the ocean. The salinity of bay water can exceed 36 during hot, dry periods in late summer and early fall (http://mddnr.chesapeakebay.net/eyesonthebay/index.cfm). Indian River Bay has a comparable water residence time, however (approximately 100 days, Cerco et al. (1994)), so this may not completely explain the differences in groundwater mixing beneath the two bays. Additional data for surface waters collected from these coastal bays at different times of the year may be helpful for understanding these mixtures.

Concentrations of ${ }^{3} \mathrm{H}$ ranged from 4.6 to $5.8 \mathrm{TU}(5.2 \pm 0.6 \mathrm{TU})$ in three samples of Chincoteague Bay surface water and one sample of Atlantic Ocean water (Fenwick Island) collected in August 2003. Four samples of fresh surface water from locations on land had ${ }^{3} \mathrm{H}$ concentrations of 5.2 to $6.5 \mathrm{TU}(5.8 \pm 0.6 \mathrm{TU})$. These new data for surface-water samples support the conclusion of Böhlke and Krantz (2003) that the ${ }^{3} \mathrm{H}$ concentrations of coastal meteoric water and estuarine surface water along the Atlantic coast in this area are similar, with an average of approximately 5 TU in 2001 to 2003. In contrast, all but one of the groundwater samples had ${ }^{3} \mathrm{H}$ concentrations less than $1 \mathrm{TU}$. Comparisons of multiple tracers generally indicate that the subestuarine ground-water samples were dominated by water that was recharged more than 50 years ago. Minor amounts of modern atmospheric tracers and younger apparent ages in the samples appear to be the result of contamination by modern (near zero age) surface water (0-20\% in most cases), possibly during drilling or well installation. The rotary drilling method used to install wells in this study differed from the vibrational one used previously (Krantz et al., 2004; Bratton et al., 2004). Future submarine groundwater investigations should make use of drilling methods that make it possible to maximize penetration depth and the ability to deploy downhole instruments, while minimizing disturbance of sediment samples and contamination of groundwater samples by drilling fluids or gases.

\subsection{Distribution and origins of nitrogen species}

\subsubsection{Nitrate and dissolved nitrogen gas}

Nitrate concentrations were near or below the detection limit in all of the pumped groundwater samples. Variable amounts of nitrate were measured in many of the ammonium-rich squeezed porewater samples, but these data are inconsistent with the other chemical features of the sediments and porewater samples, and are considered to be largely artifacts caused by nitrate production during sample handling. Therefore, the major nitrogen species in both fresh and saline subestuarine groundwater appear to be ammonium and dissolved atmospheric $\mathrm{N}_{2}$ gas.

Excess $\mathrm{N}_{2}$ that might be attributable to denitrification is indicated in both samples from Public Landing. The 8.1-m sample at this site had the most excess $\mathrm{N}_{2}$ (around $120 \mu \mathrm{M}$, equivalent to $240 \mu \mathrm{M}$ of denitrified nitrate). The excess $\mathrm{N}_{2}$ in offshore fresh groundwater at the Public Landing site is interpreted to indicate that some nitrate contamination was present in the recharge area on land and was subsequently removed during flow to the offshore sampling point. The initial concentration of nitrate in groundwater $>50$ years old implied by these data would be relatively high in comparison to the regional averages for groundwater recharged more than 50 years ago, but could be consistent with a recharge area that has been dominated by agriculture in this region for many years (Böhlke and Denver, 1995). Other deep groundwater samples collected closer to shore $(9.1 \mathrm{~m}$ below the sediment surface) and just onshore ( $23 \mathrm{~m}$ below sea level) from the PL-2003-1 site during previous investigations (Dillow et al., 2002; Bratton et al., 2004) yielded detectable nitrate (27 $\mu \mathrm{M}$ offshore, and $137 \mu \mathrm{M}$ onshore). The apparent age reported for the onshore sample was 18 years (Dillow et al., 2002).

There may be a minor amount of excess $\mathrm{N}_{2}$ near the limit of detection $(\leq 30 \mu \mathrm{M})$ in some of the South Point samples, and the $\delta^{15} \mathrm{~N}_{2}$ values of some of these $(+0.9 \%$ ) appear to be slightly elevated in 
comparison to the surface water value $(+0.6 \%)$. The three South Point samples that appear most likely to have minor excess $\mathrm{N}_{2}$ are all from within the fresh to brackish plume, the fresh component of which may have had minor amounts of nitrate in it when it was recharged on land. Excess non-atmospheric $\mathrm{N}_{2}$ could be present in saline groundwater as a result of coupled nitrification/denitrification or other processes such as anaerobic ammonium oxidation (anammox) in the ammonium-rich pore waters (Arrigo, 2005), but the data from this study cannot resolve the different pathways potentially contributing to the marginal observed variations in apparent excess $\mathrm{N}_{2}$ or $\delta^{15} \mathrm{~N}_{2}$ in some South Point samples.

\subsubsection{Nitrogen in sediments and the origin of ammonium}

Bulk nitrogen concentrations in sediments (Supplemental Material, Table C.3 and Fig. B.2) range from about 100 to $15,000 \mathrm{mg} / \mathrm{kg}$. The $\mathrm{N}$ concentrations do not vary systematically with depth. The $\delta^{15} \mathrm{~N}$ values of the sediments range from +0.2 to $+6.0 \%$. In samples with relatively high $\mathrm{N}$ concentrations, $\delta^{15} \mathrm{~N}$ values are low $(<2 \%$ ) (Supplemental Material, Fig. B.2, Table C.3); $\delta^{15} \mathrm{~N}$ values of sediments with less $\mathrm{N}$ are generally higher. These variations likely reflect differences in the sources of organic matter, because all of the high- $\mathrm{N} / \mathrm{low}-\delta^{15} \mathrm{~N}$ samples are peats, whereas the low-N/high- $\delta^{15} \mathrm{~N}$ results come from estuarine sediment samples that likely contain mostly organic matter derived from phytoplankton. Another explanation that cannot be ruled out entirely is that isotopic differences reflect different amounts of postburial $\mathrm{N}$ loss from sedimentary organic matter by isotopically fractionating processes, but the apparent overall isotope fractionation effects would be small in any case (Supplemental Material, Fig. B.2).

The ammonium concentrations in the pumped well waters range from 5 to $1540 \mu \mathrm{M}$ (Fig. 3; Supplemental Material, Table C.3). The lowest ammonium concentrations $(<20 \mu \mathrm{M})$ are in the two fresh groundwater samples offshore from Public Landing. The $\delta^{15} \mathrm{~N}$ values of ammonium in the brackish to saline groundwaters range from +3.0 to $+5.6 \%$. These values are similar to the range of estuarine sediment $\delta^{15} \mathrm{~N}$ values (Supplemental Material, Fig. B.2, Table C.3). The isotopic data are generally consistent with derivation of groundwater ammonium locally by diagenesis of organic matter in the subestuarine sediments with little or no isotopic fractionation (Lehmann et al., 2002; Prokopenko et al., 2006).

\section{Implications}

One significant result of this investigation is that shallow confining units that permit subestuarine flow of fresh or freshened groundwater far offshore, and restrict penetration of denser saline surface water, were found to be widespread within Chincoteague Bay (Fig. 9). These conditions are also likely to be common in other coastal embayments (Bratton, 2007). This directly influences both the timing and distribution of discharge of groundwater and associated nutrients to estuaries such as Chincoteague Bay. The length of time it takes for nutrients introduced to groundwater on land to reach coastal water bodies is a function of the length of the flow paths, the hydraulic gradient, and the hydraulic conductivity of the sediments. Although some groundwater discharges immediately adjacent to the shoreline, introduction of a shallow $(<10 \mathrm{~m})$ subestuarine semi-confined flow system (recharged by unconfined onshore aquifers) results in diversion of some flow up to several kilometers offshore (Bratton, 2007). This increases the travel time for groundwater prior to discharge, and results in a delayed response of water bodies to nutrient releases to groundwater associated with agricultural or residential development. This is consistent with the generally old ages ( $>50$ years) of groundwater beneath Chincoteague Bay.

Although the management implications of time lags between recharge of nutrients on land and discharge into surface waters are becoming more widely recognized (e.g., Phillips et al., 1999; Lindsey et al., 2003), the additional lags due to offshore underflow in some settings have not been appreciated or incorporated into management scenarios. In the case of narrow estuaries or those with regionally extensive confining units, underflow may completely bypass the estuary, discharging beyond barrier islands and spits into the coastal ocean. This is inferred to be the situation for northern Chincoteague Bay. In some situations, discontinuous confining units may focus discharge in offshore areas of the estuary in locations that are difficult to predict. Such focused discharge may explain anomalous patterns of eutrophication impacts, such as macroalgal blooms in areas of estuaries that are separated by some distance from obvious nutrient sources, such as has been observed in eastern Chincoteague Bay (Wazniak and Hall, 2005).

In addition to stratigraphic influences on flow and locations of discharge, there may be significant removal of nitrate by denitrification in shallow groundwater prior to discharge during offshore underflow. The availability of organic matter and associated reducing conditions in shallow subestuarine sediments may create a reaction zone that would promote nitrate loss in subestuarine groundwater that contacts these sediments along 1) offshore horizontal segments of flowpaths, or 2) offshore upward segments of flowpaths prior to discharge. Broader fresh-saline mixing zones created by these conditions are also likely to further enhance denitrification. These factors are not incorporated into most models and budgets that explicitly address groundwater inputs of nitrate to coastal zones. Breaching of shallow confining units by dredging and nearshore construction may short-circuit these reaction zones, decreasing opportunities for natural bioremediation and opening conduits for discharge of nitrate from subestuarine groundwater directly to surface waters.

Lastly, understanding of the circulation of saline surface water through subestuarine sediments at scales of meters to tens of meters is still inadequate to develop quantitative models of its impact on nutrient budgets. Ammonium released from subestuarine sediments by diagenesis and incorporated into circulating subestuarine groundwater may play a large role in nutrient delivery to estuaries such as Chincoteague Bay, but the magnitude and rates of this process are not well constrained. Data from this study, along with limited data from a previous investigation (Bratton et al., 2004), indicate the possibility of a more dynamic system of deep saline circulation beneath estuaries than has been previously recognized. This sediment source of nitrogen may be a significantly larger component of the nitrogen budget for many coastal water bodies than nitrate delivered from terrestrial aquifers. Some of the sediment-derived ammonium probably can be considered to be anthropogenic because a considerable percentage of the sedimentary organic matter in many estuaries may represent the residue of decades of excess productivity, due to eutrophication of surface waters driven by a variety of anthropogenic nutrient inputs (Herbert, 1999; Slomp and Van Cappellen, 2004).

Recent studies at other sites have demonstrated several aspects of submarine groundwater discharge that relate to the observations presented here, although direct measurement or estimation of discharge was not an objective of this study. Investigations in Massachusetts have shown that submarine groundwater discharge can be a source of other constituents to the coastal ocean besides nutrients (e.g., mercury, Bone et al., 2007). Alternatively, recirculation of saline groundwater can remove other dissolved elements from coastal surface waters (e.g., uranium, Charette and Sholkovitz, 2006). The wide zone of interaction between subestuarine fresh and saline groundwater (hundreds to thousands of meters) observed beneath Chincoteague Bay has the potential to amplify movement of a variety of important elements that are sensitive to ionic strength and redox changes into or out of estuarine sediments. The importance of bioirrigation in exchange of pore fluids in lagoon settings was highlighted by recent work in Florida (Martin et al., 2006). This is likely an important process in Chincoteague Bay as well, and may explain some of the rapid penetration of young saline water into 
groundwater beneath this estuary and similar settings (Bratton et al., 2004; Cable et al., 2004). The approach used in this investigation, particularly the greater depth and time components obtained by drilling and age dating, could be productively applied to experiments like the intercomparison studies of submarine groundwater discharge that have been done at geologically distinct sites in Florida, New York, Italy, Australia, Brazil, and Mauritius (Burnett et al., 2003, 2006).

\section{Conclusions}

This study of Chincoteague Bay confirmed results of previous offshore geophysical surveys and extended the results of adjacent studies on land. Low-salinity groundwaters were found in shallow plumes up to $8 \mathrm{~m}$ thick extending more than $1700 \mathrm{~m}$ offshore. Lowsalinity groundwater in at least one deeper, semi-confined flow system, distinct from the shallower one, passes completely beneath the northern sections of the bay and barrier island and presumably discharges into the ocean at an unknown depth. Steep salinity and nutrient gradients occur within a few meters of the sediment surface in most locations studied, with buried peats and estuarine muds acting as confining units. Groundwater ages were generally more than 50 years in both fresh and brackish waters between about 6 and $23 \mathrm{~m}$ below the bay bottom. Water chemistry indicates that freshened plumes beneath the estuary are mixtures of water originally recharged on land and varying amounts of estuarine surface water circulated through the bay floor, although some data indicate possible contamination of some samples by small amounts of surface water introduced during drilling. Ammonium, likely derived from decay of organic matter in shallow estuarine sediments, is the dominant fixed nitrogen species in the subterranean estuary locations sampled. Isotopic and dissolved-gas data indicate that denitrification within the subsurface flow system may remove much terrestrial nitrate from fresh groundwater prior to discharge to the estuary in some locations. These subterranean estuary conditions, with one or more shallow semi-confined flow systems and groundwater geochemistry strongly influenced by circulation of surface estuary water through organicrich sediments, may be common on the Atlantic margin. Additional work on seasonal variability of these systems, rates of circulation of saline surface water through sediments, and better delineation of the offshore edges of shallow and deeper confining units is necessary to fully understand the dynamics and ultimate fate of submarine groundwater, and its impact on the coastal ocean.

\section{Acknowledgments}

Field assistance was provided by B. Sturgis (NPS-Assateague Island National Seashore); S. Kelsey and D. Koopmans (USGS-Woods Hole/ ETI, Inc.); A. Norton (University of Toledo); and J. Earle (USGS-WRDDenver). M. Stawas and K. Plowman of Hillis-Carnes Engineering, Inc. operated the drilling rig. The drilling barge and tug were provided by D. Sharp of Hi-Tide Marine Construction, and operated by T. Gargliano. Nutrient analyses were done by K. Savidge (Univ. of Delaware). ${ }^{3} \mathrm{H}-{ }^{3} \mathrm{He}$ analyses were done under contract by Lamont-Doherty Earth Observatory, with assistance from B. Turrin. Other gases and isotopes were analyzed at USGS by P. Widman, G. Casille, J. Wayland, J. Hannon, S. Mroczowski, H. Qi, R.L. Michel, and others. Symbols used in Fig. 9 were courtesy of the Integration and Application Network (ian.umces. edu/symbols/), University of Maryland Center for Environmental Science. Primary funding was provided by USGS (Coastal and Marine Geology Program and National Research Program in Water Resources) with additional material support from the National Park Service (C. Zimmerman) and the University of Toledo. J. Crusius, K. Kroeger, and several anonymous reviewers provided helpful comments on drafts of this manuscript. Any use of trade, product, or firm names is for descriptive purposes only and does not imply endorsement by the U.S. Government.

\section{Appendix A. Supplemental Material}

Supplemental Material associated with this article can be found, in the online version, at doi:10.1016/j.marchem.2009.01.004.

\section{References}

Accomack County Planning Commission, 1997. The Accomack County Comprehensive Plan. Aeschbach-Hertig, W., Peeters, F., Beyerle, U., Kipfer, R., 1999. Interpretation of dissolved atmospheric noble gases in natural waters. Water Resources Research 35, 2779-2792.

Andres, A.S., 1991. Results of the coastal Sussex County, Delaware ground-water quality survey. Report of Investigations No. 49, Delaware Geological Survey, Newark, DE.

Arrigo, K.R., 2005. Marine microorganisms and global nutrient cycles. Nature 437, 349-355.

Atkinson, M.J., Smith, S.V., 1983. C:N:P ratios of benthic marine plants. Limnology and Oceanography $28,568-574$.

Böhlke, JK, 2006. Tracermodel1-Excel workbook for calculation and presentation of environmental tracer data for simple groundwater mixtures. Use of Chlorofluorocarbons in Hydrology - a Guidebook, Section III.10.3: Vienna, International Atomic Energy Agency, STI/PUB/1238, pp. 239-243.

Böhlke, J.K., Coplen, T.B., 1995. Interlaboratory comparison of reference materials for nitrogen-isotope-ratio measurements. Reference and Intercomparison Materials for Stable Isotopes of Light Elements. IAEA-TECDOC, vol. 825. International Atomic Energy Agency, Vienna, pp. 51-66.

Böhlke, J.K., Denver, J.M., 1995. Combined use of groundwater dating, chemical, and isotopic analyses to resolve the history and fate of nitrate contamination in two agricultural watersheds, Atlantic coastal plain, Maryland. Water Resources Research 31, 2319-2339.

Böhlke, J.K., Krantz, D.E., 2003. Isotope geochemistry and chronology of offshore ground water beneath Indian River Bay, Delaware. USGS Water-Resources Investigations Report 03-4192.

Bone, S.E., Charette, M.A., Lamborg, C.H., Gonneea, M.E., 2007. Has submarine groundwater discharge been overlooked as a source of mercury to coastal waters? Environmental Science \& Technology 10 (1021/es0622453).

Boynton, W.R., Murray, L. Kemp, W.M., Hagy, J.D. Stokes, C. Jacobs, F., Bowers, J., Souza, S., Krinsky, B., Seibel, J., 1993. Maryland's Coastal Bays: An Assessment of Aquatic Ecosystems, Pollutant Loadings, and Management Options. Maryland Department of the Environment, Baltimore, MD.

Bratton, J.F., 2007. The importance of shallow confining units to submarine groundwater flow. In: Sanford, W., Langevin, C., Polemio, M., Povinec, P. (Eds.), A New Focus on Groundwater-Seawater Interactions, vol. 312. International Association of Hydrological Sciences Publication, pp. 28-36.

Bratton, J.F., Böhlke, J.K., Manheim, F.T., Krantz, D.E., 2004. Ground water beneath coastal bays of the Delmarva Peninsula: Ages and nutrients. Ground Water 42, 1021-1034.

Bullister, J.L., Wisegarver, D.P., Menzia, F.A., 2002. The solubility of sulfur hexafluoride in water and seawater. Deep-Sea Research. Part I. Oceanographic Research Papers 49, 175-187.

Burnett, W.C., Bokuniewicz, H., Huettel, M., Moore, W.S., Taniguchi, M., 2003. Groundwater and pore water inputs to the coastal zone. Biogeochemistry 66, 3-33.

Burnett, W.C., Aggarwal, P.K., Aureli, A., Bokuniewicz, H., Cable, J.E., Charette, M.A., Kontar, E., Krupa, S., Kulkarni, K.M., Loveless, A., Moore, W.S., Oberdorfer, J.A., Oliveira, J., Ozyurt, N., Povinec, P., Privitera, A.M.G., Rajar, R., Ramessur, R.T., Scholten, J., Stieglitz, T., Taniguchi, M., Turner, J.V., 2006. Quantifying submarine groundwater discharge in the coastal zone via multiple methods. Science of the Total Environment 367, 498-543.

Busenberg, E., Plummer, L.N., 1992. Use of chlorofluorocarbons $\left(\mathrm{CCl}_{3} \mathrm{~F}\right.$ and $\left.\mathrm{CCl}_{2} \mathrm{~F}_{2}\right)$ as hydrologic tracers and age-dating tools: The alluvium and terrace system of central Oklahoma. Water Resources Research 28, 2257-2283.

Busenberg, E., Plummer, L.N., 2000. Dating young groundwater with sulfur hexafluoride; natural and anthropogenic sources of sulfur hexafluoride. Water Resources Research 36, 3011-3030.

Cable, J.E., Martin, J.B., Swarzenski, P.W., Lindberg, M.K., Steward, J., 2004. Advection within shallow pore waters of a coastal lagoon, Florida. Ground Water 42, 1011-1020.

Cerco, C.F., Bunch, B., Cialone, M.A., Wang, H., 1994. Hydrodynamics and eutrophication model study of Indian River and Rehoboth Bay, Delaware. Technical Report EL-94-5. U.S. Army Corps of Engineers.

Charette, M.A., Sholkovitz, E.R., 2006. Trace element cycling in a subterranean estuary: part 2. Geochemistry of the pore water. Geochimica et Cosmochimica Acta 70, 811-826.

Cook, P.G., Herczeg, A.L. (Eds.), 2000. Environmental Tracers in Subsurface Hydrology. Kluwer Academic Press, Norwood, MA, 529 pp.

Coplen, T.B., 1988. Normalization of oxygen and hydrogen isotope data. Chemical Geology (Isotope Geoscience Section) 72, 293-297.

Demarest, J.M., 1981. Genesis and preservation of Quaternary paralic deposits on Delmarva Peninsula. Doctoral dissertation, University of Delaware.

Denver, J.M., 1986. Hydrogeology and geochemistry of the unconfined aquifer in WestCentral and Southwestern Delaware. Report of Investigations No. 41. Delaware Geological Survey, Newark, DE.

Denver, J.M. 1989. Effects of agricultural practices and septic-system effluent on the quality of water in the unconfined aquifer system in parts of Eastern Sussex County, Delaware. Report of Investigations No. 45. Delaware Geological Survey, Newark, DE.

Dillow, J.J.A., Greene, E.A., 1999. Ground-water discharge and nitrate loadings to the coastal bays of Maryland. USGS Water Resources Investigations Report 99-4167. 
Dillow, J.J.A., Banks, W.S.L., Smigaj, M.J., 2002. Ground-water quality and discharge to Chincoteague and Sinepuxent Bays adjacent to Assateague Island National Seashore, Maryland. USGS Water Resources Investigations Report 02-4029.

Gallardo, A.H., Marui, A., 2006. Submarine groundwater discharge: an outlook of recent advances and current knowledge. Geo-Marine Letters 26, 102-113.

Hannon, J.E. and Böhlke, J.K., 2008. Determination of the $\delta\left({ }^{15} \mathrm{~N} /{ }^{14} \mathrm{~N}\right)$ of ammonium $\left(\mathrm{NH}_{4}^{+}\right)$in water: RSIL Lab Code 2898. In: Révész, K., Coplen, T.B. (Eds.), Methods of the Reston Stable Isotope Laboratory, U.S. Geological Survey, Techniques and Methods, book 10, sec. C, chap. 15.

Herbert, R.A., 1999. Nitrogen cycling in coastal marine ecosystems. FEMS Microbiology Reviews 23, 563-590. doi:10.1111/j.1574-6976.1999.tb00414.x.

Holmes, R.M., McClelland, J.W., Sigman, D.M., Fry, B., Peterson, B.J., 1998. Measuring ${ }^{15}$ N$\mathrm{NH}_{4}^{+}$in marine, estuarine and fresh waters: an adaptation of the ammonia diffusion method for samples with low ammonium concentrations. Marine Chemistry 60, 235-243.

Hulth, S., Aller, R.C., Canfield, D.E., Dalsgaard, T., Engström, P., Gilbert, F., Kristina Sundbäck, K., Thamdrup, B., 2005. Nitrogen removal in marine environments: recent findings and future research challenges. Marine Chemistry 94, 125-145.

Jordan, T., 2004. Net Anthropogenic Nitrogen Inputs to Coastal Bay Watersheds... and Nitrogen Discharges from the Watersheds. Coastal Bays Nutrient Budget Workshop, Baltimore, Maryland. 22 November 2004. WWW page, http://www.dnr.state.md. us/coastalbays/water_quality/nutr_min.html [accessed 12 December 2005].

Krantz, D.E., Manheim, F.T., Bratton, J.F., Phelan, D.J., 2004. Hydrogeologic setting and ground water flow beneath a section of Indian River Bay, Delaware. Ground Water 42, 1035-1051.

Lehmann, M.F., Bernasconi, S.M., Barbieri, A., McKenzie, J.A., 2002. Preservation of organic matter and alteration of its carbon and nitrogen isotope composition during simulated and in situ early sedimentary diagenesis. Geochimica et Cosmochimica Acta 66, 3573-3584.

Lindsey, B.D., Phillips, S.W., Donnelly, C.A., Speiran, G.K., Plummer, L.N., Böhlke, J.K., Focazio, M.J., Burton, W.C., 2003. Residence time and nitrate transport in ground water discharging to streams in the Chesapeake Bay Watershed. USGS WaterResources Investigations Report 03-4035.

Ludin, A., Weppernig, R., Bönisch, G., Schlosser, P., 1998. Mass spectrometric measurement of helium isotopes and tritium. Lamont-Doherty Technical Report 98-06.

Manheim, F.T., Gieskes, J.M., 1984. Interstitial water methods. In: Heath, G.R. (Ed.), Sedimentology, Physical Properties, and Geochemistry in the Initial Reports of the Deep Sea Drilling Project Volumes 1-44: An Overview. World Data Center for Marine Geology and Geophysics, Boulder, CO, Report MGG-1, pp. 163-176.

Manheim, F.T., Brooks, E.G., Winters, W.J., 1994. Description of a hydraulic sediment squeezer. USGS Open-File Report 94-0584.

Manheim, F.T., Krantz, D.E., Bratton, J.F., 2004. Studying ground water under Delmarva coastal bays using electrical resistivity. Ground Water 42, 1052-1068.

Martin, J.B., Cable, J.E., Jaeger, J., Hartl, K., Smith, C., 2006. Thermal and chemical evidence for rapid water exchange across the sediment-water interface by bioirrigation in the Indian River Lagoon, Florida. Limnology and Oceanography 51, 1332-1341.

Miller, K.G., McLaughlin, P.P., Browning, J.V., Benson, R.N., Sugarman, P.J., Hernandez, J., Ramsey, K.W., Baxter, S.J., Feigenson, M.D., Aubry, M.-P., Monteverde, D.H., Cramer B.S., Katz, M.E., McKenna, T.E., Strohmeier, S.A., Pekar, S.F., Uptegrove, J., Cobbs, G., Cobbs III, G., Curtin, S.E., 2003. Bethany Beach Site. In: Miller, K.G., Sugarman, P.J., Browning, J.V., et al. (Eds.), Proc. ODP, Init. Repts., 174AX, pp. 1-84. WWW page, http://www-odp.tamu.edu/publications/174AXSIR/VOLUME/CHAPTERS/174AXS_3. PDF [accessed 16 November 2005].

Moore, W.S., 1996. Large groundwater inputs to coastal waters revealed by ${ }^{226} \mathrm{Ra}$ enrichments. Nature 380, 612-614.

Niencheski, L.F.H., Windom, H.L., Moore, W.S., Jahnke, R.A., 2007. Submarine groundwater discharge of nutrients to the ocean along a coastal lagoon barrier, Southern Brazil. Marine Chemistry 106, 546-561.
Owens, J.P., Denny, C.S., 1978. Geologic Map of Worcester County. Maryland Geological Survey, Baltimore, MD

Phillips, S.W., Focazio, M.J., Bachman, L.J., 1999. Discharge, nitrate load, and residence time of ground water in the Chesapeake Bay watershed. USGS Fact Sheet FS-150-99.

Plummer, L.N., Busenberg, E., Drenkard, S., Schlosser, P., Ekwurzel, B., Weppernig, R. McConnell, J.B., Michel, R.L., 1998. Flow of river water into a karstic limestone aquifer 2. Dating the young fraction in groundwater mixtures in the Upper Floridan aquifer near Valdosta, Georgia. Applied Geochemistry 13, 1017-1043.

Pritchard, D.W., 1960. Salt balance and exchange rate for Chincoteague Bay. Chesapeake Science 1, 48-57.

Prokopenko, M.G., Hammond, D.E., Berelson, W.M., Bernhard, J.M., Stott, L., Douglas, R. 2006. Nitrogen cycling in the sediments of Santa Barbara Basin and eastern subtropical North Pacific: nitrogen isotopes, diagenesis and possible chemosymbiosis between two lithotrophs (Thioploca and Anammox)-“riding on a glider". Earth and Planetary Science Letters 242, 186-204.

Qi, H., Coplen, T.B., Geilman, H., Brand, W.A., Böhlke, J.K., 2003. Two new organic reference materials for $\delta^{13} \mathrm{C}$ and $\delta^{15} \mathrm{~N}$ measurements and a new value for the $\delta^{13} \mathrm{C}$ of NBS 22 oil. Rapid Communications in Mass Spectrometry 17, 2483-2487.

Rozan, T.F., Taillefert, M., Trouwborst, R.E., Glazer, B.T., Ma, S., Herszage, J., Valdes, L.M., Price, K.S., Luther III, G.W., 2002. Iron-sulfur-phosphorus cycling in the sediments of a shallow coastal bay: implications for sediment nutrient release and benthic macroalgal blooms. Limnology \& Oceanography 47, 1346-1354.

Schlosser, P., Stute, M., Dörr, H., Sonntag, C., Münnich, K.O., 1988. Tritium/3 He dating of shallow groundwater. Earth and Planetary Science Letters 89, 353-362.

Shedlock, R.J., Denver, J.M., Hayes, M.A., Hamilton, P.A., Koterba, M.T., Bachman, L.J., Phillips, P.J., Banks, W.S.L., 1999. Water-quality assessment of the Delmarva Peninsula, Delaware, Maryland, and Virginia-results of investigations, 1987-91. USGS Water-Supply Paper 2355-A.

Slomp, C.P., Van Cappellen, P., 2004. Nutrient inputs to the coastal ocean through submarine groundwater discharge: controls and potential impact. Journal of Hydrology 295, 64-86.

Stute, M., Schlosser, P., 2000. Atmospheric noble gases. In: Cook, P.G., Herczeg, A.L. (Eds.), Environmental Tracers in Subsurface Hydrology. Kluwer Academic Press, Norwood, MA, pp. 349-377.

Swarzenski, P.W., Orem, W.H., McPherson, B.F., Baskaran, M., Wan, Y., 2006a Biogeochemical transport in the Loxahatchee River estuary, Florida: the role of submarine groundwater discharge. Marine Chemistry 101, 248-265.

Swarzenski, P.W., Burnett, W.C., Greenwood, W.J., Herut, B., Peterson, R., Dimova, N., Shalem, Y., Yechieli, Y., Weinstein, Y., 2006b. Combined time-series resistivity and geochemical tracer techniques to examine submarine groundwater discharge at Dor Beach, Israel. Geophysical Research Letters 33, L24405. doi:10.1029/2006GL028282.

Taniguchi, M., Burnett, W.C., Cable, J.E., Turner, J.V., 2002. Investigation of submarine groundwater discharge. Hydrological Processes 16, 2115-2129.

Vacher, H.L., 1988. Ground water in barrier islands: theoretical analysis and evaluation of the unequal-sea level problem. Journal of Coastal Research 4, 139-148.

Wazniak, C.E., Hall, M.R. (Eds.), 2005. Maryland's Coastal Bays: Ecosystem Health Assessment 2004. Maryland Department of Natural Resources, Tidewater Ecosystem Assessment, Annapolis, MD. DNR-12-1202-0009.

Weiss, R.F., 1970. The solubility of nitrogen, oxygen, and argon in water and seawater. Deep-Sea Research 17, 721-735.

Weiss, R.F., 1971. Solubility of helium and neon in water and seawater. Journal of Chemical and Engineering Data 16, 235-241.

Wells, D.V., Conkwright, R.D., 1999. Maryland coastal bays sediment mapping project: physical and chemical characteristics of the sediments - Atlas and synthesis report. Coastal and Estuarine Geology File Report No. 99-5. Maryland Geological Survey, Baltimore, MD. On CD-ROM.

Worcester County Planning Commission, 2006. The Comprehensive Development Plan Worcester County, Maryland. 